\title{
Embedding Cultivated Diversity in Society for Agro-Ecological Transition
}

\author{
Véronique Chable ${ }^{1, *}$, Edwin Nuijten ${ }^{2}$, Ambrogio Costanzo ${ }^{3}$, Isabelle Goldringer ${ }^{4}{ }^{\oplus}$, \\ Riccardo Bocci ${ }^{5}$, Bernadette Oehen ${ }^{6}$, Frédéric Rey ${ }^{7}$, Dionysia Fasoula ${ }^{8}$, Judit Feher ${ }^{9}$, \\ Marjo Keskitalo ${ }^{10}$, Beate Koller ${ }^{11}$, Michalis Omirou ${ }^{12}$, Pedro Mendes-Moreira ${ }^{13}$ (D), \\ Gaëlle van Frank ${ }^{4}$ (D) Abdel Kader Naino Jika ${ }^{4}$, Mathieu Thomas ${ }^{14}$ and Adanella Rossi 15 \\ 1 INRAE, UMR BAGAP (Biodiversity, Agroecology and Landscape management), 65 rue de Saint Brieuc, \\ 35042 Rennes, France \\ 2 Louis Bolk Institute, Hoofdstraat 24, 3972 LA Driebergen, The Netherlands; e.nuijten@debeerschehoeve.nl \\ 3 Organic Research Centre, Trent Lodge, Stroud Road, Cirencester GL7 6JN, UK; \\ ambrogio.c@organicresearchcentre.com \\ 4 Université Paris-Saclay, INRAE, Université Paris-Sud, CNRS, AgroParisTech, UMR GQE-Le Moulon, \\ 91190 Gif-sur-Yvette, France; isabelle.goldringer@inrae.fr (I.G.); gaelle.van-frank@inra.fr (G.v.F.); \\ kaderjika@gmail.com (A.K.N.J.) \\ 5 Rete Semi Rurali, Via di Casignano 25, 50018 Scandicci (FI), Italy; riccardo.bocci@semirurali.net \\ 6 FiBL-Research Institute of Organic Agriculture, 5070 Frick, Switzerland; bernadette.oehen@fibl.org \\ 7 ITAB (Institut Technique de l'Agriculture Biologique), 149 Rue de Bercy, 75012 Paris, France; \\ frederic.rey@itab.asso.fr \\ 8 Department of Plant Breeding, Agricultural Research Institute, 1516 Nicosia, Cyprus; dfasoula@ari.gov.cy \\ 9 ÖMKi, Hungarian Research Institute of Organic Agriculture, Miklós tér 1, 1033 Budapest, Hungary; \\ judit.feher@biokutatas.hu \\ 10 LUKE, Natural Resources Institute Finland, FI-31600 Jokioinen, Finland; marjo.keskitalo@luke.fi \\ 11 ARCHE NOAH, Obere Straße 40, A-3553 Schiltern, Austria; beate.koller@gmx.net \\ 12 Department of Agrobiotechnology, Agricultural Research Institute, 1516 Nicosia, Cyprus; \\ michalis.omirou@ari.gov.cy \\ 13 Instituto Politécnico de Coimbra, Escola Superior Agrária de Coimbra, Bencanta, 3045-601 Coimbra, \\ Portugal; pmm@esac.pt \\ 14 CIRAD, UMR AGAP Univ Montpellier, CIRAD, INRA, Montpellier SupAgro, F-34398 Montpellier, France; \\ mathieu.thomas@cirad.fr \\ 15 Department of Agriculture, Food and Environment, University of Pisa, 56124 Pisa, Italy; \\ adanella.rossi@unipi.it \\ * Correspondence: veronique.chable@inrae.fr
}

Received: 31 October 2019; Accepted: 14 January 2020; Published: 21 January 2020

check for updates

\begin{abstract}
Agroecology calls for a global approach, integrating scientific, practical, and advocacy dimensions, to redesign agricultural systems based on ecological and socio-cultural processes and emphasizing biodiversity. This review is grounded on the results of DIVERSIFOOD, a European H2020 multi-actor research project, and explores the concept of cultivated diversity using various dimensions relevant to foster sustainable organic food systems and agro-ecological transition. From the evaluation of underutilized genetic resources and forgotten crops, DIVERSIFOOD has proposed plant breeding strategies, on-farm experimentation, and statistical tools to create new populations, landraces, and organic cultivars with intra-varietal diversity. The added value of Community Seed Banks and forms of collective seed management in Europe have been described in terms of goals and activities, and their value for improving seed regulations, treaties, and genetic resources management is discussed. In the context of the current agro-food system characterized by standardization, DIVERSIFOOD raised awareness of qualities of 'biodiverse food systems' in which all actors have a role to play. It highlighted the critical capacity to preserve a diversity of cultural values embodied in 'biodiverse products', thereby involving consumers in collective strategies for reviving diversity,
\end{abstract}


and empowering all actors of organic food systems to really and efficiently implement research within their farms and networks.

Keywords: agrobiodiversity; agroecological transition; biodiverse food systems; participatory research; genetic resources; community seed bank; organic plant breeding; multi-actor approach

\section{Introduction}

Agroecology calls for an integrated and global approach of agricultural systems, embracing scientific, practical, and advocacy dimensions, aiming to redesign agricultural production systems based on their underlying ecological processes [1]. Agroecology proposes sustainable alternatives to the industrial agricultural model that emerged after the Second World War and the economic, social, and environmental unbalances it entails [2]. Whilst worldwide agricultural production based on agroecology is an achievable, yet not an easy, goal, several studies have proposed and characterized transition pathways of gradual changes in agriculture at various scales to move away from conventional-industrial systems [3]. Transition steps as summarized by Gliessmann [4] include (i) increased input efficiency, (ii) substitution of industrial inputs with alternative inputs and practices, and (iii) redesign of the system based on a set of ecological processes. These three steps, mostly focusing at a farming system scale, would ideally be integrated with two other steps aiming to (iv) re-establish connections between food users and producers and (v) a worldwide new food system instead of a linear value chain. However, this transition is far from being simple. In fact, many authors suggest that the transition is locked in the step of "increased efficiency", whereas "redesign", or "biodiversity-based agriculture", is relegated to a niche [5]. This is also due to a conflicting debate between an 'agroecological' vision (which is holistic) and a 'biological-science' vision (which is reductionist). The latter vision is by far dominant in EU policy, although significant openings towards more systemic and global approaches in the current decade cannot be neglected [6]. Furthermore, most agroecological research focuses on cropping systems management, whereas there is still insufficient explicit account for the role of seeds and genetic resources, as an integral part of agro-ecological system redesign, rather than mere inputs [7].

There is an increasing awareness of the opportunity of biodiversity to ensure sustainable livelihoods and hence food security and nutrition. Biodiversity, at every level from genes to ecosystems, is fundamental to produce food in a wide range of ecological and socio-economic environments. It increases resilience to shocks and stresses, provides opportunities to adapt production systems to emerging challenges, and is a key resource to increase output in a sustainable way [8]. In the past few years, a radical change has been called by many actors in society [9]. One of the key-message of the IPES (International Panel of Experts on Sustainable Food systems) report in 2016 [10] was "What is required is a fundamentally different model of agriculture based on diversifying farms and farming landscapes, replacing chemical inputs, optimizing biodiversity and stimulating interactions between different species, as part of holistic strategies to build long-term fertility, healthy agro-ecosystems and secure livelihoods, i.e., 'diversified agroecological systems'.".

In Europe, the hegemony of modern varieties has reduced farmers' and users' knowledge and know-how in terms of plant breeding and seed production. Seed has a central role as it is an integral part of all dimensions of the agro-ecosystem. Seed incorporates two types of knowledge, the first about their biology and heredity, and the second related to the socio-cultural dimension of the societies that manage them. In fact, according to a definition proposed by the FAO (Food and Agriculture Organization), traditional knowledge can be considered an integral part of agrobiodiversity, because it is formed and preserved by human activity [11].

In 2014, the European Commission launched the 8th Framework Programme for Research and Innovation (2014-2020), named H2020, to support progress towards sustainable food production systems. Priority has been given to improve the use of genetic resources supporting agricultural diversity and 
regional products. In parallel, another concept has emerged in 2012 'the European Innovation Partnership for Agricultural productivity and Sustainability' (EIP-AGRI) which has been launched to contribute to the European Union's strategy 'Europe 2020' [12]. To achieve this aim, the EIP-AGRI brings together innovation actors (farmers, advisors, researchers, businesses, Non Governmental Organizations) and helps to build bridges between research and practice: a multi-actor and transdisciplinary research was encouraged to cross-pollinate all forms of knowledge. In this context, DIVERSIFOOD, one of the first $\mathrm{H} 2020$ research projects, aimed to enlarge the circle of actors committed to increasing diversity in agriculture and active management of genetic resources in local contexts.

\section{General Context}

\subsection{From Genetic Resources to Cultivated Diversity}

\subsubsection{Development of the Concept of Genetic Resources in the World}

Throughout history, thousands of plant species have been domesticated and used in agriculture. Most of them are now underutilized [13]. Of a total of 250,000 identified plant species, 7000 have been used in agriculture throughout human history [14]. However, currently, $75 \%$ of the world's food come from only 12 plant and five animal species, and $60 \%$ of total worldwide caloric input comes from just three plant species: rice, wheat, and maize [14]. Crop diversity decreased dramatically at multiple levels: less species are cultivated, less genetic diversity is used within species and, last but not least, cultivated populations have been increasingly replaced by genetically homogeneous cultivars (such as clones, pure lines, or F1 hybrids) since the beginning of the 20th century. Such homogenization of crops, extended to cropping systems and products, is a very recent phenomenon considering the long history of agriculture, and is part of the process that, following the Industrial Revolution, transformed agriculture as an industrial activity.

In parallel, efforts have been made to preserve the diversity that was increasingly excluded from commercial production. The first collections of seeds/plants considered as a "resource" for genes to be used in plant breeding have been concomitant with the increasing awareness that genetic diversity is the foundation for genetic advancement, as a consequence of the discovery of the Mendelian laws in the late 19th century. It was during the 1920s and 1930s that the most thorough, famous, and large collections were created by the work of Vavilov at St. Petersburg [15].

The successes of plant breeding, in particular as part of the Green Revolution during the 1960s, with the widespread diffusion of high-yielding varieties of staple crops at the expenses of farmers' populations (or "landraces") and their associated genetic diversity, has eroded the "genetic foundation" of its own success. It was in this context of abrupt homogenization and industrialization of agriculture that the concept of "genetic resources" was formalized. The unintended reduction of cultivated diversity lead to the first FAO technical conferences on genetic resources in the 1960s in which international coordination of conservation and "proper use" of global nature were encompassed through the concepts of 'inventory', 'conservation', and 'use' of its "components", i.e., "genetic resources" [16].

The idea of "genetic resources" evolved further alongside two social and cultural trends: (1) the genetic vision of living beings, i.e., the idea that the diversity of life is played out essentially at the level of the gene, and (2) the resources conception of the Earth. According to the latter, the Earth became a storehouse of "dormant reserves", being either minerals or living beings, to be harnessed and mobilized by breeding companies [16]. As a result, genetic resources were increasingly seen, rather than an asset whoever was free to mine as a natural resource under the sovereignty of public authorities, whose conservation was linked to their sustainably use, and whose benefit should be equitably shared [17]. These are the three fundamental points of the Convention on Biological Diversity (CBD) ratified in 1992 during the World Summit of Heads of State in Rio de Janeiro, at the occasion of the United Nations Conference on Environment and Development (UNCED). Since this date, genetic resources had lost their specific status of Common Heritage of Humankind (as defined in the International Undertaken of the FAO) [18]. The CBD became operational and binding to the signatory countries in December 1993. 
To date, there are 193 acceding countries (the Parties). From a North-South perspective, the game on the international chessboard sees, on the one hand, the countries of the South of the world as suppliers of organic raw materials, who claim their economic rights, and on the other hand the countries of the North, holders of technologies and with the ability to invest in the sector.

Further developments of the concept "genetic resources" accompanied the rise of new knowledge and management perspectives. The problem of conservation was extended to "renewal of cultivated biodiversity", whose value was increasingly framed through the prism of "ecosystem services" [19].

As early as 1984, Altieri had claimed for a more inclusive vision of genetic resources, open to social and cultural dimensions: "it is time to recognize the active role of peasants in genetic resource conservation. Socio-cultural issues make it impossible to view the resources merely as a set of genes that can simply be conserved by sticking them into a gene bank. If isolated from the folk science and traditional uses of the cultures that have nurtured them, they lose part of their value or culturalhistorical meaning." [20].

These developments have led to a more ecological framing of genetic resources, with the contribution of landscape ecology and conservation biology. From mere 'stocks of genes' an increased emphasis was put on flows, connectivity, resilience, adaptation, and coevolution. The range of legitimate epistemic knowledge around cultivated biodiversity was likewise broadened, encompassing anthropology, evolutionary and population genetics, dynamic management, conservation biology and its modelling approaches, participatory methodologies, new ways of measuring diversity cultivated in the wake of international initiatives for the development of biodiversity indicators [19].

\subsubsection{Conserving and Using Genetic Resources in Europe}

In Europe in the late 1960s, the European association for research on plant breeding (EUCARPIA) began to cooperate for the conservation of genetic resources and mainly supported the ex situ conservation of genetic resources which should guarantee facilitated access for breeders and seed companies. Within the EUCARPIA Gene Bank Committee, the idea emerged of strengthening European cooperation in the area of genetic resources and thus the need to create the European Cooperative Program for Genetic Resources (ECPGR). A program directly coordinated by the European Community began its activities in 1979. Before this date, several programmes on genetic resources, scattered across Western, Eastern, Southern, and Northern Europe, have existed in the field of conservation of genetic resources but they were not coordinated. The program carried out by ECPGR "for better use of gene banks and resistance breeding" is part of the "agricultural research programme". The actions have had some success and led to the creation of the EURISCO internet search platform which "serves as a central point of access within a network of national information systems that store and manage data on plant genetic resources" [21]. The awareness from ECPGR that diversity is renewed thanks to in situ and on-farm management, started only in the 2000s in Europe [22].

Since the 1990s, European programmes have been implemented to continue collection efforts and to characterize collections, e.g., GENRES I (1994) and GENRES II (2004) programmes mainly managed by breeders and private seed companies who had a direct interest in genetic resources being collected through gene banks for the development of new varieties, and use by the scientific community.

Since 2014, under the initiative of the European Parliament, the European Commission (DG Agriculture and Rural Development) launched two "Preparatory action on EU plant and animal genetic resources in agriculture" for a period of five years to recognize the potentials for the added value of genetic resources, to identify stakeholders with concrete examples to valorize the use of neglected breeds and varieties in an economically viable way [23]. The action was a success, at least for some of the case studies promoted by the project as for example the traditional product (Gwell cheese) from local breed, "La bretonne pie noir", boost on the market [24].

Meanwhile European H2020 research calls, under the framework the Societal Challenges 2 for "Food security, sustainable agriculture and forestry", enhanced these ambitions to increase the use of genetic diversity in agriculture and forestry in Europe "recognizing this diversity as a prerequisite to 
ensure food security, productivity as well as resilience of crops, forests and animals vis-à-vis biotic and abiotic threats in changing environments".

The EU Commission wished to provide the basis for products with a regional identity for which there is increased consumer interest. Finally, the challenge of these $\mathrm{H} 2020$ projects was to restore all their values (agricultural and socio-cultural) to a patrimony stored in genebanks or thanks to seed savers to be still preserved on-farm encouraging their broader use in breeding activities, in farming, and in the whole food chain. DIVERSIFOOD was one of these projects with these aims.

\subsubsection{Context of Plant Breeding and Seeds for Organic Agriculture}

Organic agriculture has long been one of the key catalyzers of innovations towards more agro-ecological cropping systems. Nevertheless, advancements in organic plant breeding have been more limited and much slower than in organic crop management. In fact, whilst nearly $60 \%$ of seeds used in the organic sector are certified organic, thus produced according to the rules of organic farming, very few varieties are bred organically, i.e., the plant breeding process of varietal development should take place in organic conditions and must comply with the guiding principles of organic agriculture $[25,26]$. The main reasons for the slow development of organic plant breeding are a lack of return on investment and the absence of adapted rules for variety registration for organic bred varieties [27]. Furthermore, there are no specific variety testing protocols for organic farming, which could impair varietal choice, nor for description of heterogeneous cultivars. All modern varieties have been bred to fit industrialized value chains, meaning homogeneous and phenotypically stable crops aimed to maximize input responsiveness and farming efficiency, but cannot cope well with organic farming and its diversified agroecosystems in which no chemicals are used to adapt plants to their environment [28]. Organic farming pioneers, one century ago, have underlined the highest importance of diversity since all the living beings are interdependent, meaning all are contributing to the resilience of the food systems, and their health is also interlinked.

The organic sector has agreed international sets of principles, values, and practices, under the flag of IFOAM (International Federation of Organic Agricultural Movements, Bonn, Germany). As part of their standards, IFOAM has adopted standards for organic seed production, and drafted standards for organic plant breeding in collaboration with ECO-PB (European Consortium for Organic Plant Breeding). One pillar of the plant breeding standards is the ability of plants to reproduce and the respect of the integrity of living entities which logically follow from the IFOAM principles [29]. That means that living beings are respected in their specific function and structure, i.e., "the integrity of plants refers to their way of being, their wholeness, completeness, their species-specific characteristics, and their being in balance with the species-specific environment" [24].

As genetic diversity is a fundamental basis, organic plant breeding should "improve the genetic diversity of crops, and thus contribute to the promotion of agro-biodiversity". Moreover, another goal relates to quality: "organic plant breeding should support sustainable food security, food sovereignty, secure supply of plant products (e.g., fiber, medicine, timber), and the common welfare of society by satisfying nutritional quality needs of animal and human beings" [30].

\subsection{Community Seed Bank and Collective Management of Diversity}

For centuries, farmers around the world have been responsible for generating, diffusing, and conserving agro-biodiversity before the development of a formal seed sector. Traditionally, farmers have used self-saved seed, farmer-to-farmer exchanges, and local market purchases. Year after year, with cycles of sowing and resowing seed lots plant populations, the more adapted plants contribute to increase the fitness of those populations generation after generation [31]. The farmer seed production practices and knowledge are slowly disappearing in Europe and in most industrialized countries in the world. The so-called collective seed saving is a relative more recent practice that emerged only towards the end of the 1980s as a reaction to the agricultural modernization and industrialization as well to the inter- and intra-national trade and intellectual property policies, that together shaped the 
current global agro-food system. The roots and evolution of Community Seed Banks (CSBs) as well as the present-day context in which they operate can be traced along a broader social and geopolitical timeline [32].

Multiple initiatives have supported farmers and local communities to regain or maintain their own seeds. They strengthened collective forms of cooperation among farmers involved in maintaining and improving local seed systems, especially focused on local varieties for the conservation and sustainable use of agricultural biodiversity. These collective initiatives have taken various forms and names: community gene bank, farmer seed house, seed hut, seed wealth center, seed-savers group, association or network, community seed reserve, seed library, and community seed bank. They support diverse activities such as local farmer research groups, participatory plant breeding, seed-saver and seed exchange networks, seed production cooperatives, and networks of custodian farmers [32]. In the South, pioneers organized various types of community seed banks, such as in Bangladesh, Brazil, Ethiopia, India, Nepal, Nicaragua, the Philippines, and Zimbabwe. In the North, the seed-savers networks in Australia, Canada, the UK, and the USA were the first community seed banks to be created [32].

Until very recently, few scientific studies have been published about the community seed banks' forms of management, use, and conservation of genetic resources. Shrestha and colleagues observed that no report of their existence can be found in the FAO's "Second global report on the state of the world's genetic resources for food and agriculture" (2010) [33]. Even if some authors between 1997 and 2010 specified their existence for conservation of genetic resources diversity, nobody stated that it was farmers and gardeners who have set up collective seed organizations, so-called community seed banks, around the world [33].

\subsection{Challenges of Embedding Genetic Diversity in Food Systems}

The current food system is characterized by a highly standardized and monotonous offer produced in an impoverished agriculture. Most of producers and consumers have little or no awareness of genetic diversity and the related qualitative properties of food products. This mirrors the lack of attention paid to agrobiodiversity in the course of development of the agro-food system, rather aimed at goals of standardization, uniformity, and productivity.

There is now a wide acknowledgment that enriching agrobiodiversity is essential to increase the resilience, adaptability, and health of food systems [34-37]. Looking at the diversification of the genetic foundations of food through a comprehensive vision, that, as other studies have highlighted, integrates sustainability of food systems and sustainable diet [34,38,39], a sustainable reviving of cultivated diversity demands the building of well-functioning supply chains and the (re)introduction of the derived 'biodiverse products' in the consumption practices. The cultural and economic appreciation of the diversity values embodied in biodiverse products can allow the reproduction of the system and the related resources (Figure 1).

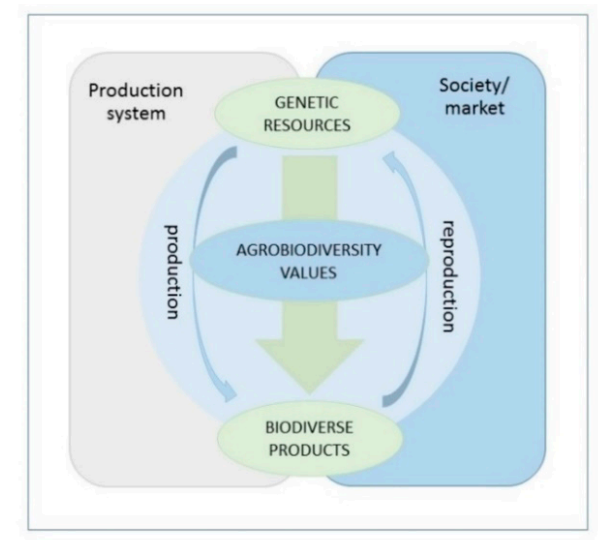

Figure 1. The virtuous circle of sustainable management of genetic resources. 
Considering agrobiodiversity as a public good, this challenge can be read also in other terms, referring to the failures of the market and public policies [40]. Today, the public values provided by agrobiodiversity conservation are not rewarded in the market. The dominant food system, and the related model of cheap food pursued by agroindustry [41], has required homogeneity and stability of raw material supply and has molded the public regulatory and support systems consequently. In this context, farmers have been heavily affected by the conditioning coming from the input market (including the seed market) and the distortive effects of the subsidies system, losing interest in and knowledge of more diversified varieties. The direct acknowledgement of agrobiodiversity values in the market is one of the possible mechanisms to solve this situation $[40,42-46]$. At the same time, there is a need to properly understand and face this approach. Both supply chain actors and consumers must become aware of the specific values attached to biodiverse crops and foods and act accordingly.

Reintroducing diversity in food systems is a complex process, which requires significant changes in production systems and diet patterns. It starts with the development of awareness of the multiple values of agrobiodiversity (ecological, social, cultural, and ethical) and the (capacity and willingness of) translation of this awareness into consistent practices. These processes cover all aspects of the food system - breeding, farming, food processing, and consumption. Conceiving food systems as socio-ecological systems [39], embedded in institutional-legal frameworks, these processes involve different domains, which refer to technical, organizational, economic, cultural, social, institutional, legal, and political dimensions, often interdependent. As well, these processes develop through the interactions among and contributions of multiple actors, diversely involved and bearers of different experiences and perspectives.

The above described complexity shows the importance of adopting a comprehensive and systemic approach in dealing with agrobiodiversity enhancement, as well as the need to pay particular attention to the dynamics that develop from the interaction among the various actors involved and the related potential in supporting the needed changes. As in other processes of collectively driven innovation [47], social learning plays a key role [48]. It underpins significant processes of awareness raising and empowerment, alignment around shared visions and goals, cocreation of new practices, and development of new agency [49]. These processes take place in the relational structures within locally based networks, complemented by broader connections established among similar pathways or other networks. Such an approach is considerably more complex than conventional marketing strategies to promote products in the market [50].

\section{Concepts and Outcomes from the DIVERSIFOOD Project}

The objective of DIVERSIFOOD was to embed and to enrich diversity in the food system, mainly organic systems, to promote local, high quality food thanks to demonstrative activities based on 15 crop species. The multi-actor research process itself has been embedded in its environmental and social contexts, and has been based on a decentralized and participatory, instead of a usual top-down, approach. In fact, all relevant actors with different working backgrounds within the food system to enrich cultivated biodiversity were involved in testing, renewing, and promoting underutilized or forgotten crops, species, and varieties. This paper aims to share the main results and key lessons from the DIVERSIFOOD project, covering complementary approaches connected with crop diversity for resilient sustainable food systems:

- Underutilized/forgotten crops: concepts and outcomes of multi-actor and on-farm evaluation, as a key step to revive cultivated diversity;

- New approaches of plant breeding for diversified and sustainable farming systems;

- Community agrobiodiversity management (CAM) as a key element of on-farm management strategies;

- Diversity and sustainability within food systems: new relationships among actors, supporting local short and fair supply chains and reconnecting farmers and consumers; 
- Paradigm shift for multi-actor and transdisciplinary research, to tackle technological and regulation bottlenecks for organic and agro-ecological food systems.

\subsection{Building on Underutilized Crops}

Creating a knowledge base on underutilized crops was a starting point to increase diversification of European cropping systems, and was one of the main tasks of the DIVERSIFOOD project. To this aim a working definition had been formulated as follows [51]: an underutilized crop is "a genetic resources with limited current use and potential to diversify and improve cropping systems and supply chains in a given context". Whilst acknowledging most of the existing literature and definitions [52-55], this wording bears two key innovations to align the underutilized crops problem with the agroecological transition framework: (i) a shift in focus from the (underutilized) plants to the processes of their (re)introduction, and (ii) a clear acknowledgment that these processes are related to a context.

\subsubsection{Contextualization and Processes of (re)Introduction of Underutilized Crops}

Contextualization is a key aspect of the shift from a standardized, conventional setting of agriculture towards agroecology, i.e., "a way of redesigning food systems, from farm to fork, with the goal of achieving ecological, economic and social sustainability" [4]. The concepts of agroecological transition mentioned in the first paragraph of this paper do not acquire practical meaning unless the context of application is made explicit, both in terms of scale, that can span from the cultivation system on a parcel of land, to the overall food system, and, in terms of factors, which can be of biophysical, socio-economic, and political order. At which scale level should crop diversity be increased? A lot of emphasis is generally placed on the 'local food systems' [56] that, unless the extent of the scale of the 'local' is specified, risk being as generic and misleading as the "wide adaptation" paradigm that has characterized much of mainstream plant breeding in the past six decades [57]. In fact, as far as biophysical factors are concerned, the target scale to increase crop diversity can be, for example, either a single farm or an entire country looking for alternatives to a few mainstream crops. Once the context is defined, increase of crop diversity in food systems is far from being a straightforward process. In fact, at least three distinct, yet possibly overlapping processes can take place.

The first one, and the most aligned with the common framework of neglected and underutilized species, is the one of reintroducing species that have been lost along the way of agricultural industrialization in the past seven decades. This process calls for a rediscovery of genetic resources as well as of the practical knowledge that has been lost with the abandoned cultivated species. One notable example is rivet wheat (Triticum durum subsp. turgidum), a close relative of durum wheat widespread in mountainous and/or cool climates of Western Europe at one time, with a high competitive ability and adapted to poor fertility [58]. Research on and breeding of rivet wheat genetic resources were carried out e.g., in England in the 1930s but the crop has been largely abandoned in the post-World-War-Two era $[59,60]$. In DIVERSIFOOD, genetic resources of rivet wheat have been extensively tested in France, the United Kingdom, and the Netherlands, showing the overall good performance compared to commercial wheat in marginal arable lands and a wide diversity of quality and technological traits.

The second process is introducing, in a specific geographical area, new species that might be common elsewhere, in other words the extension of cultivation areas. A species might be introduced in a new geographical context either because its area is simply extending, or because other regions are offering new putative adaptive contexts. In the first case, area shifts are nowadays well documented as an effect of climate change, reportedly projected to allow e.g., a northward shift of the overall agricultural climate zone [61]. Shifting cultivation areas is also a key tool to counteract adverse effects of climate change, especially in particularly exposed regions and farming systems. A remarkable example is that of participatory tree domestication programs in the west-African Sahel where tree genetic resources for planting in the local agroforestry parklands are deliberately collected from drier regions as a strategy to increase the long-term drought-resilience of the system [62]. In the second case cultivation extension, cultivation areas can jump over large geographical barriers. This is not a new 
process: it has indeed shaped food systems across the world throughout human history, resulting in regions and countries whose agricultural and food systems have depended since centuries to a large extent on cultivating crops of foreign origin [63]. The process is still ongoing with two main trends. Species that start to be cultivated commercially in a region whose climate is not too dissimilar from their home region, as e.g., for quinoa in Europe, constitute an important trend that can contribute to increasing crop diversity. A second trend is plants following human migrations: 'exotic' crops are introduced on a non-commercial basis, grown in allotments for family consumption as part of growers' cultural heritage, and are rarely surveyed and subject to formal documentation and conservation [64].

The third process is the use of alternative genetic structures of common species. As explained in Section 2.2, the loss of diversity is not only a shrinking number of species, but also an overwhelming loss of genetic diversity within the commonly used species. The overall marketed seeds are developed for highly standardized agricultural systems with standardized practices and markets. Hence, for many crops, crop phenotypic diversity is drastically reduced to a few standard crop types, consisting of varieties with high levels of uniformity such as pure line varieties and F1-bybrids. Increasing genetic and phenotypic diversity of common species is a key process to enable diversity in cropping and food systems. To increase resilience of agro-ecosystems, and especially for agroecological transition, it is widely recognized that diversity is a central prerequisite to substantially improve ecosystem functions [28]. Similar to what happens when reintroducing forgotten species, creating a value chain of e.g., non-hybrid germplasm implies a drift from mainstream cropping systems, processing, and markets and bears opportunities for organic and low-input cultivation. In fact, with the reduction of external inputs, resulting in higher exposure to environmental variability, within-crop diversity can result in a key resource to ensure stability, resilience, and possibly progressive adaptation to local conditions. Notably, this process spans across a 'rediscovery of the old' forgotten varieties and/or landraces and the constitution and testing of 'new', innovative cultivar concepts, such as cereal composite cross populations (CCPs) [65]. Tomato landraces [66], broccoli open-pollinated varieties, composite cross populations of common wheat (Triticum aestivum), maize (Zea mays [67]), and buckwheat (Fagopyron esculentum) [68] are examples of cases investigated in DIVERSIFOOD, providing evidence of their within-crop diversity as well as of their phenotypic divergence from mainstream pure lines and/or F1-hybrids. An example is a Breton farmers' network who characterized populations of buckwheat according to their performance (yield and flour yield, average grains weight, agronomic characteristics, suitability for different outlets, and organoleptic properties). Farmers have developed mixtures and composite cross populations to associate complementary traits and to apply mass selection. A similar process is currently ongoing using 200 buckwheat accessions from several European genebanks in the West of France.

Whilst the rediscovery of forgotten species mainly faces practical and economic constraints, genetic diversification within species also encounters obstacles in case of registration in the legislative structure developed by and for mainstream agriculture, such as the UPOV (international Union for the Protection Of new Varieties of plants) convention and national and international seed legislation (European catalogue and seed certification for seed marketing). In fact, the official conditions for cereal seed certification, namely the "sufficient identity and varietal purity" (Art. 1, 66/402/EEC), effectively ruled out any marketing of cereal seed which was not distinct, uniform, and stable in appearance, until a 'temporary experiment', under the Commission Implementing Decision 2014/150/EU, allowed marketing of 'populations' of wheat, oats, barley, and maize, under quantitative restrictions. The legality of genetically heterogeneous seed of species and genetic structures not covered by the above 'temporary experiment' is currently under discussion in the context of the Revised Organic Regulation that will come into force in 2021. 


\subsubsection{Overall Outcomes of Evaluation of Underutilized Crops}

In DIVERSIFOOD, a series of parallel experiments with underutilized genetic resources has been carried out based on the underlying hypothesis that reintroducing genetic resources with a status of underutilization can have benefits in provisioning agroecosystem services and supporting local value chains of high-quality products, in the overall context of agroecological systems and circular economy. The focus of these experiments was therefore not only on their agronomic description, but rather on their food system performance, i.e., the capacity and effectiveness to provide multiple services in given contexts. Crop "evaluation" was dissected into four main dimensions, strictly connected with one another, yet all with a value of their own: (i) crop descriptors, i.e., those phenotypic traits useful to identify a genetic resource; (ii) agroecosystem performance, as a driver of environmental fitness; (iii) productive performance, as a driver of yield potential; (iv) quality performance, as a driver of success in local, high-quality value chain [69].

As far as crop descriptors are concerned, two main observations emerged. First of all, some traits which had been lost during the modern breeding period, have reappeared, including undesirable traits that have been bred against and might also have played a role in the abandonment of certain phenotypes. Examples are brittle rachis in einkorn (Triticum monococcum) or excessive straw length and lodging sensitiveness in ancient wheat species (Triticum dicoccon, Triticum turgidum) and varieties. Second, single accessions of genetic resources show considerable within-crop phenotypic diversity, which can either be because of their genetic structure, them being landraces or open-pollinated varieties (OPVs) or composite cross populations or result from intentional or even accidental mixtures.

Agroecosystem performance was evaluated from different angles, mostly looking at weed competitiveness, pest and disease resistance, and abiotic stress tolerance. A particular focus has been given to interaction of plants with soil microorganisms. In fact, high fertilization and intensive crop protection have also affected the ability of plants from modern varieties to establish beneficial associations with soil functional microbial assemblages, like mycorrhizal fungi and symbiotic nitrogen fixing bacteria. For two species, maize and chickpeas, we have explored how integrated strategies in plant breeding can include soil microbial communities studies. Molecular fingerprinting showed that arbuscular mycorrhizal fungi (AMF) diversity is partially associated to maize and Cyprus chickpea landraces' productivity and this is related with the plant genotype [70], shedding light on how plant-microbe interaction can be harnessed in different species.

Productive performance highlighted a, perhaps expected, trend: yield of underutilized crops can be a serious limiting factor, as the tested material can be either low-yielding or difficult to harvest, but, in many cases, can be a solution for marginal conditions.

Quality performance was also well evaluated from different angles, namely (i) processing quality, (ii) nutritional and nutraceutical quality, (iii) organoleptic quality, and (iv) intangible value. Main highlights under these points are that a diversity of crops results in a diversity of products that need adaptation in the processing, which makes artisanal processing and short supply chains more suited in first instance, as well as in the methods and concepts to assess their quality [69].

The overall outcome of performance evaluation of underutilized crops is the high genotype-byenvironment interaction. This appeared clearly at the level of agroecosystem, productive and quality performance, as highlighted in an experiment on emmer, einkorn, and rivet wheat in different rotational position and soil management conditions [71]. Deploying and testing genetic resources in multiple farms rather than in centralized research stations is therefore essential, as a basis for greater emphasis on genotype-by-environment interaction in breeding [72,73]. To this end, the way information is managed, stored, and made available also needs innovation to effectively account for complex interactions, as attempted by the DIVERSIFOOD Database on the performance of underutilized crops [74]. 


\subsection{New Plant Breeding Strategies for Diversity and On-Farm Experimentation Concepts}

Within DIVERSIFOOD plant breeding methods and tools were tested, elaborated, and implemented in order to learn how to create new diversified cultivars, mainly populations, to build up agro-eco resilience and to provide high quality food. The main achievements were (i) the development of new populations, (ii) the development of methods, in particular of adapted statistic tools, and (iii) the implementation of participatory plant breeding (PPB) programs on a range of important crops and vegetables in Europe such as bread and durum wheat, maize, tomato and broccoli, buckwheat, barley, lupine, carrots, onions, and faba beans.

\subsubsection{Breeding of New Diversified Populations}

To valorize and to increase cultivated diversity, DIVERSIFOOD has developed three activities: (i) constituting new populations, (ii) organizing participatory plant breeding with several actors and developing several innovative designs, and (iii) improving methods and tools to carry out on-farm experimentations for population breeding and evaluation. The development of new populations is needed, apart from developing material for local context, for the revival and renewal of diversity of agricultural genetic resources (GR) beyond the GR conserved in genebanks. Accessions from ex situ conservation conditions lost their intrinsic diversity level during conservation processes: the regeneration of genebanks samples cannot be performed in large fields because of the large number of accessions they have to manage. New diversity, besides ex situ GR diversity, is also needed since the climatic and environmental conditions changed since the storage of GR in genebanks. Thanks to on-farm breeding under organic conditions and community seed management, numerous crop populations were able to evolve and to adapt to local conditions. The new diversity was developed through several breeding strategies relying only on natural methods (crossings and mixtures) respecting the natural biological barriers between species and according to the IFOAM draft standards for organic plant breeding [75]. Figure 2 illustrates all forms of diversified cultivars that can be encountered with less to more diversity, developed through plant breeding.

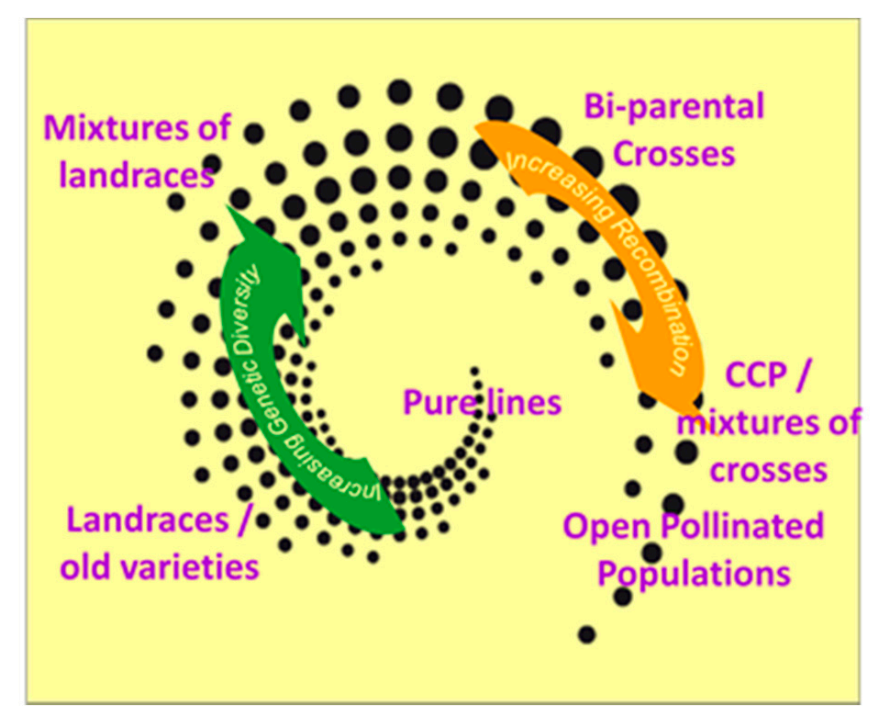

Figure 2. Scheme of the different types of population genetic structure ranged according to their increasing level of diversity and recombination.

In PPB, farmers and the other actors usually aim at developing varieties with a certain level of diversity, i.e., population-varieties, which are suited to their specific environmental conditions, farming practices, and marketing objectives. Pure lines, old varieties, and landraces (Figure 1) may be used as a source of diversity for participatory plant breeding to create new diversified populations. The pure lines, old varieties, and landraces may be mixed and multiplied for several generations to 
form dynamic populations such as in the case of bread wheat by INRA and ITAB (Institut Technique de l'Agriculture Biologique) in France. They also may be crossed to create simple bi-parental segregating populations or more complex Composite Cross Populations (CCPs) based on the crossing of multiple parents as it was done on bread wheat in France [75,76]. Studying the effect of the origin and type of parents in bread wheat bi-parental crosses, INRA and RSP (French network for peasant seed) found that although populations derived from crosses including as parent one recent variety bred under organic farming had significantly higher yields on average, several populations derived from crosses between landraces and historic varieties were as productive. These show the value of using these varieties as a source in of diversity in decentralized PPB. Original and interesting CCP populations have also been developed for lupin by FiBL (Forschungsinstitut für biologischen Landbau)—Research Institute of Organic Agriculture in Switzerland and for bread wheat in Italy by RSR (Rete Semi Rurali). In France, INRA and ITAB compared dynamic populations and CCP of bread wheat, and have created the same types of experimental populations for buckwheat. In Portugal IPC (Instituto Politécnico de Coimbra) analyzed the creation of a maize CCP 'Fandango' since the 1970s that is still under selection at farmers' fields [77]. The specificity is that for all situations, performance and quality as they have been determined by actors, were the indicators of the collective progresses.

\subsubsection{Genetic Hypotheses Underlying Decentralized Plant Breeding Process}

As in the official registration system for crop varieties, the Value for Cultivation and Use (VCU) of the candidates populations are assessed based on their yield averaged over a set of trials carried out under standardized conditions (sometimes including both conventional and without fungicide treatments such as in France, https://www.geves.fr/wp-content/uploads/BLE-1.pdf), the classical centralized breeding tends to have the objective of improving the overall genetic potential $(G)$ of the breeding lines. Then following Gallais [78] (pp. 362-363), in the quantitative genetic theory, the expected response on the overall genetic potential $G$, by selecting on the average phenotypic value $P$. over all testing environments (usually experimental stations), can be expressed as

$$
R=\mathrm{S} * \frac{\operatorname{cov}(P ., G)}{\operatorname{var}(P .)}=S * \frac{\operatorname{var}(\mathrm{G})}{\operatorname{var}(G)+\frac{1}{n E}(\operatorname{var}(E)+\operatorname{var}(G x E))+\frac{1}{n E x n R} \operatorname{var}(e)},
$$

with S, the selection differential, $n E$ (resp. $n R$ ) the number of environments (resp. the number of replicates in each environment), $E$ the effect of environment, $G x E$ the interaction between the genetic value and the environment, $e$ the within environment residual effect and $\operatorname{var}()$ states for the variance of a random variable and $\operatorname{cov}()$ for the covariance between two random variables.

In that case, for a given $S$ (selection differential), environmental effect and $G \times E$ interactions limit selection efficiency and the option is to increase the number of environments and to use environments made homogeneous and similar (through inputs and choosing quality soils), thus minimizing $G \times$ $E$ interactions.

On the contrary, in decentralized on-farm breeding, it has been shown that the environments are very contrasting due to diverse pedo-climatic conditions associated to various agroecological farming practices, and that $G \times E$ interactions can be strong [73]. Therefore, the improvement of the overall genotypic value $(G)$ would be difficult and is not interesting, and the objective is rather to improve the local genetic value which also includes the interaction with the local environment, i.e., $G_{l o c}=G+$ $\left(G x E_{l o c}\right)$. Then, selection is applied based on the local phenotypic value $P_{l o c}$, i.e., the value of the lines or populations evaluated in each local environment, and following Gallais [78] in the quantitative genetic theory, the expected response on the local genetic value $G_{l o c}$, by selecting on the local phenotypic value $P_{l o c}$ can be written as:

$$
\begin{array}{r}
R_{l o c}=\mathrm{S} * \frac{\operatorname{cov}\left(P_{l o c}, G_{l o c}\right)}{\operatorname{var}\left(P_{l o c}\right)}=S * \frac{\operatorname{var}\left(G_{l o c}\right)}{\operatorname{var}\left(G_{l o c}\right)+\frac{1}{n R} \operatorname{var}(e)} \\
=S * \frac{\operatorname{var}(G)+\operatorname{var}(G x E)}{\operatorname{var}(G)+\operatorname{var}(G x E)+\frac{1}{n R} \operatorname{var}(e)} .
\end{array}
$$


It can be noted that the $G \times E$ interactions contribute to both denominator and numerator therefore leading to no limiting effect on the response to selection. Hence, when facing a wide diversity of agroecological environments and practices, decentralized breeding is the most efficient strategy to select varieties adapted to local agroecosystems, possessing the relevant traits as farmers select knowing their environments and practices $[79,80]$. Indeed, this is an extension of the approach of specific-adaptation breeding strategy based on the selection in specific environments or conditions such as the one proposed by Annicchiarico [81].

\subsubsection{Adapting Tools for Decentralized Experimentation}

Decentralized plant breeding requires particular methods specifically adapted to on-farm experiments and breeding (i.e., numerous, small, unreplicated/unbalanced trials) and user-friendly tools available to the members of participatory breeding groups. All methodological aspects (i.e., organization, participation, trials, statistical analyses, quality tests, selection) need to be specifically designed to fit each crop species and adapted to decentralized selection and to the context of the stakeholders involved (i.e., farmers, breeders, processors, consumers).

PPB uses the experimental methods of decentralized breeding. A decision tree (Figure 3), that can be found in a technical booklet [75], has been developed within DIVERSIFOOD, describing the possible experimental designs and statistical methods of analysis that can be carried out, according to the objectives and the experimental constraints of the breeding program and the farmers' group, with a focus on cereal crops. Depending on the objectives of the experiments, the decision tree points to several methods based on different experimental designs that require specific conditions (e.g., number of plots per location; of replicated germplasms within and between locations). Most of the statistical methods have been implemented in an R Package: PPBStats, whose code is hosted on: https://github.com/priviere/PPBstats.

Data analysis from PPB programs may have one or several objectives that will condition the experimental device and the methods to use. Therefore, the first step in designing a PPB experiment is to identify these objective(s) (identified in green on the decision tree, Figure 3). They can either be to:

- (i) improve the prediction of a target variable for selection by analyzing agronomic and nutritional traits;

- (ii) compare different varieties or populations evaluated for selection in different locations by analyzing agronomic and nutritional traits, and taste through sensory analysis;

- (iii) study the response of varieties or populations under selection over several environments by analyzing agronomic traits;

- (iv) study diversity structure and identify parents to cross based on either good complementarity or similarity for some traits by analyzing agronomic traits and molecular data;

- (v) study networks of seed circulation by analyzing network topology. 


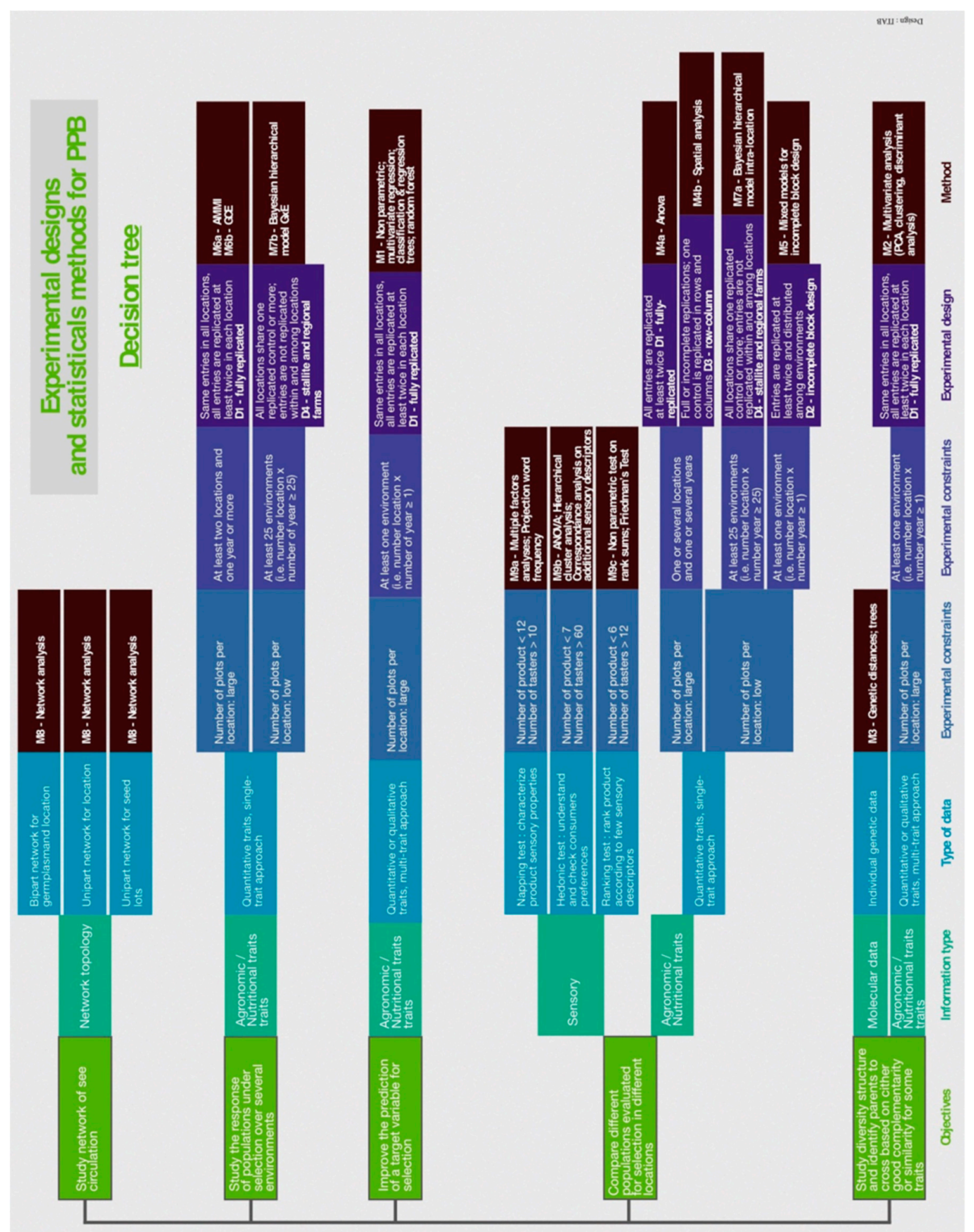

Figure 3. Decision tree to select experimental designs and statistical methods according to the objectives and the constraints of the participatory plant breeding (PPB) project. 
The methods can be applied to four types of information: agronomic and nutritional data, sensory data, network topology of the seed circulation, and molecular data. Different experimental designs (identified in purple on the decision tree, Figure 3) permit these methods to be implemented: fully replicated block design, incomplete block design row-column design, and satellite-farms and regional-farms. Depending on the objectives, the design and the type of data, different statistical methods (in brown on the decision tree, Figure 3) can be applied: non parametric methods, multivariate analyses (PCA), genetic distances and trees, ANOVAs, spatial analysis, mixed models for incomplete block designs, models dealing with genotype by environment interaction such as AMMI and GGE, Bayesian hierarchical models, network analysis, napping tests, hedonic tests, and ranking tests.

At least 124 improved populations and varieties of bread wheat, spring wheat, einkorn, durum wheat, barley, maize, faba bean, white lupin, tomato, onion, and carrots, with new or specific quality traits have been developed through on-farm participatory plant breeding. These new varieties and populations will contribute to increase productivity, economic gains, and agricultural sustainability due to their higher quality or improved adaptation to organic farming and specialized systems. Some of these populations-cultivars have already been adopted by farmers and adapted to their farming system, as the seeds are multiplied on-farm and exchanged within the network of actors, involved in the research process.

The methods tested have been specifically designed to fit each crop species and to be adapted to decentralized selection and to the context of the stakeholders involved (i.e., farmers, breeders, processors, consumers). Multi-actor meetings have been organized to bring out demands and needs for the research. The transdisciplinary dimension and the multi-actor approach needed for its development integrates four main components:

- Genetic resources (access, choice, and management);

- Techniques: (i) Breeding and management of populations (CCP, dynamic mixtures, farmer mass selections, OPV); (ii) Statistical tools-Experimental designs for on-farm trials, Statistical methods for analysis; (iii) Quality assessment (nutritional, sensory or end-use, depending on the needs of the network);

- Social aspects (multi-actor meetings, joint decision making, awareness raising, education, and training);

- Legislation (awareness raising, networking, and lobbying).

The integration of these components allows the understanding of how a PPB program works and a better communication on the objectives of the group (Figure 4). Figure 4 describes the various activities by the partners that are part of a PPB strategy. The different activities conducted in the four main components are described in detail in Appendix A. 


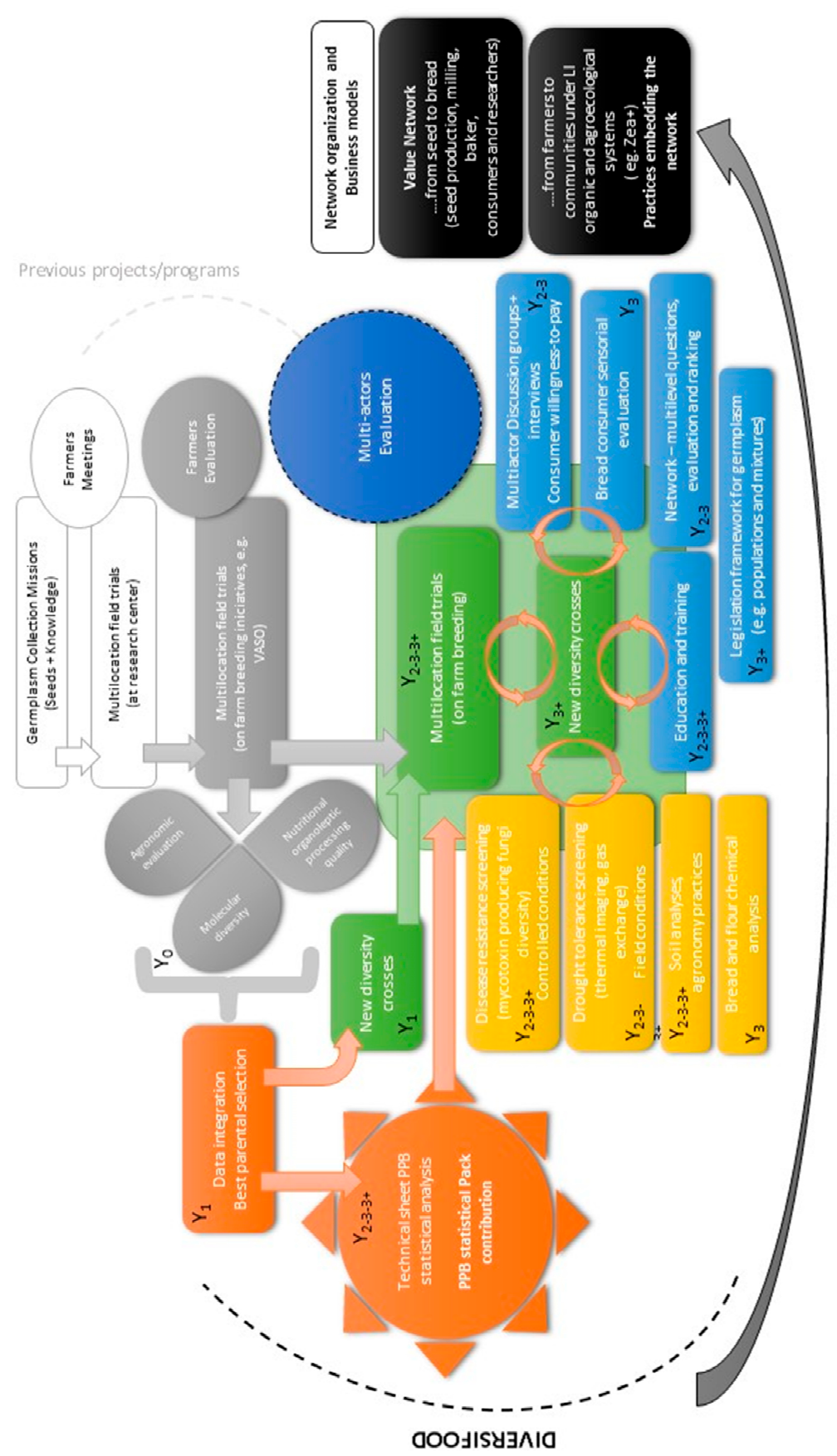

Figure 4. Interrelationship between components of a multi-actor and participatory plant breeding program such as (1) Genetic resources; (2) Techniques (3) Social aspects, and (4) Legislation to understand the management of all activities from seeds to networks organization. In white, the beginning of the process, with objective definition and genetic resources collection; in grey, management of on-farm trials; in orange: actions linked to data analysis; in yellow, tools for performance and quality assessment in the fields and on the product (from field to plate); in green, activities to manage diversity; in blue, organization of actors outside the farm; in dark grey, elements of the network organization and its economic model. $\mathrm{Y}$ means the year when some tasks were developed during the project.

\subsection{Community Agrobiodiversity Management and Community Seed Banks}

A thorough understanding of the forces that shape cultivated diversity in different contexts allows to identify those experiences that have a key role in contributing to new approaches to the seed systems that can be referred to Community Agrobiodiversity Management (CAM). CAM [82] is a concept that 
describes the different types of actions that can be done on the farm with seeds and varieties (Figure 5) from on-farm conservation to the creation of new diversity thanks to Participatory Plant Breeding. It represents a dynamic vision of cultivated diversity and includes farmers' innovation.

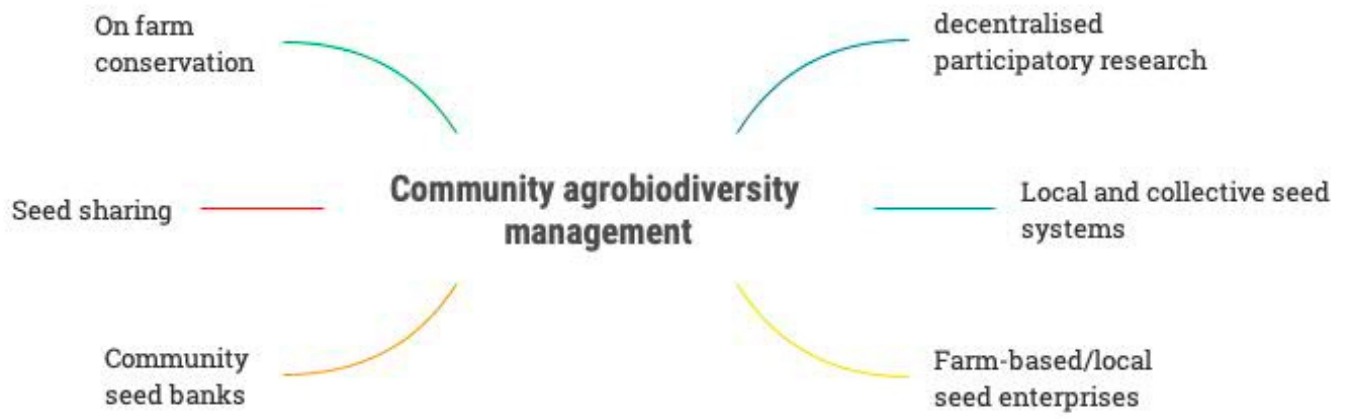

Figure 5. Actions on seed and varieties part of the concept of Community Agrobiodiversity Management [82].

Over the past 20 years CAM initiatives involved in the management of crop diversity have emerged in Europe $[83,84]$ Among those, farmers' seed networks or community seed banks now include more diverse actors in addition to farmers, such as gardeners, small seed producers, etc. Their objectives are to establish resilient agricultural production systems that better cope with global changes by the reappropriation of their seed production.

From an evolutionary point of view, the crop varieties under on-farm dynamic management can be considered as a crop metapopulation as each variety consist in a genetically heterogeneous population grown by a different actor, possibly connected by seed flows to the others, each population being likely to become extinct (due to crop failure or seed loss in storage) [85]. They are considered as generally adapted to specific local conditions or practices and with a certain capacity to evolve in response to natural or human selection. In addition, when seeds of these varieties circulate among actors, they may be confronted to new practices and environmental conditions and therefore subject to various selection pressures $[86,87]$. Seed circulation between farmers is therefore a major driver determining the dynamics of genetic diversity over time. Although several studies have shown that seed flows between farmers have a strong influence on the evolution of crop genetic diversity, there is a lack of knowledge on how seed circulation, farmers' practices, and local selection pressures interact to shape the structure of crop genetic diversity over time. Hence, the contribution of the intertwined social and biological processes involved in crop genetic diversity evolution and its adaptation to different environmental and social contexts remain largely unexplored due to the complexity of the processes involved.

\subsubsection{Assessment of the Impact of Social Network and Seed Exchange on Crop Genetic Diversity}

In DIVERSIFOOD a participatory modelling approach was proposed to help separate the respective effects of the different processes through going back and forth between observations and simulations. The objectives were (i) to support a reflexive approach to CAM actors to help them in organizational decision-making; (ii) to develop scientific expertise on on-farm diversity management strategies based on a collaborative work between researchers and actors of the seed networks. For that, a simulation software (CropMetaPop, https://sourcesup.renater.fr/www/cmp/\#mozTocId328861) has been developed to model the evolution of the genetic diversity of cultivated populations by taking into account growers' practices and their social organization. Social organization is assumed to determine the way seed can circulate among the actors. In addition, a demo-genetic analysis pipeline [88] was designed to analyze the model outputs and represent them graphically. Meetings were organized with the facilitators of CAMs in France (RSP), Italy (RSR), and Spain (RAS) to document the species and varieties they manage, their growing practices, seed circulation rules, and organizational characteristics. This information allowed to co-construct scenarios for community-based management of crop diversity. Initial scenarios 
were simulated, and the results discussed with the facilitators. New scenarios can be proposed from these discussions in an iterative process.

A first investigation of simple theoretical case studies showed that seed circulation among actors allows to ensure the survival rate of the separate populations therefore avoiding the extinction of the metapopulation in the long term. Three types of seed circulation networks have been investigated: (i) a decentralized network that represents a situation where everyone has the same social status, and therefore the same number of social relationships; (ii) a centralized network that represents a situation where few actors are at the center and through which all information circulates; (iii) a community network that represents a situation where actors are organized into subgroups, such as local organizations, and exchange more information within their group than between groups. At the genetic level, the type of seed circulation network significantly influenced the genetic differentiation among populations, in particular for crop populations of limited size (less than 100 plants). Centralized networks appeared to have the strongest homogenizing effect, probably due to a limited number of actors distributing seeds to everyone. In the real case studies, interviews with farmers and farmers' organization facilitators were essential to describe the general trends and specificities from one CAM to another. Although the approach was conducted with four CAMs located in three different countries and managing two different crops, the results consistently showed that all in CAMs, very diverse and contrasting local conditions were met in terms of both environments and practices. A similar general dynamic of seed circulation was observed among the CAMs, with the organization changing from star network to community network when the number of actors increased.

This participatory approach based on codesigning scenarios of community seed systems functioning showed that the collective dimension of CAM is a key element for seed circulation which allows for crop diversity development and maintenance. Therefore, this is important to support the various and collective organizations involved in the management, conservation, and breeding of crop genetic diversity.

\subsubsection{Describing Community Seed Banks in Europe}

Community seed banks (CSBs) constitute the social structures of collective seed management in the so-called informal seed system. We note that CSBs have been founded worldwide since the 1970s in many parts of the world. The main aim of CSBs is to address the loss of agrobiodiversity and to enhance access to seeds adapted to local conditions that the market does not provide for adequately. The activities of CSBs are also connected to participatory approaches of community crop management and plant breeding. They represent the seed management place (one site or a network of sites) of CAM. The term CSB however does not relate to a standardized concept, methodology, or a certain form of social organization, but encompasses social initiatives of various forms and functions.

DIVERSIFOOD aimed to understand the current functions and the future directions in the evolution of existing experiences of Community Seed Banks, using a global approach. In the last years CSBs have been perceived as an interesting practice from developing countries, although the contribution of DIVERSIFOOD to this field of study has been to focus on experiences from Europe, by looking at the potential role of CSBs in innovative seed systems. Based on transdisciplinary research and participatory methods, the project created an area for exchange of experiences and dialogue on the issue of CSBs in Europe.

However, very little research has been done on CSBs in Europe. DIVERSIFOOD therefore wanted to shed light on the situation and development of CSB initiatives in Europe, following a double aim: (i) documenting the long history, numbers, and diversity of European CSB initiatives aimed at raising awareness on the political level, and (ii) feeding research results into a process of self-awareness, self-reflection, and innovation within the European CSB network. An online map resulting from a survey of 84 initiatives was set up as a tool to support networking and exchange within the CSB movement as well as with other stakeholders, within Europe and beyond (www.communityseedbanks.org). 
As an overall result, the survey showed that the number of community seed banks in Europe had been rapidly growing since 2005, at least in some European regions. However, most initiatives did not use the term "community seed banks" themselves. They identified themselves as "networks", "houses", "libraries", or "archives" for seeds (and other plant propagation parts). This diversity of synonyms reflects the general diversity within the CSB movement in Europe, also in terms of age, size, goals, stakeholder groups, areas, and activities, as well as organizational structures. In fact, most CSBs in Europe have emerged locally from grassroot initiatives.

Although older CSBs in Europe, seed-savers' movements in the USA and Australia, or social movements in the global South did serve as role models, these were adapted and developed by European CSBs according to their local conditions and needs. CSBs in southern and western European countries were mainly initiated and run by farmers, whereas in northern and central European countries a leading role was taken by private gardeners. Many initiatives shifted their approach from a mainly conservation to a more evolutionary one, as the goals of crop adaptation and participatory plant breeding acquired importance. CSBs managed, on average, several hundreds of accessions, mainly local and farmers' varieties and old commercial varieties, but also own breeding populations.

CSBs in Europe considered the impact of their training and awareness raising activities as a major achievement. The lack of financial resources, leading to a shortage of manpower and technical equipment, as well as poor regulatory conditions, were mentioned as most important obstacles. Key strategies to overcome these barriers were seen to be networking among CSBs inside and beyond Europe, mutual support and learning, and cooperation with other stakeholders sharing similar goals and values. Furthermore, the positive image and credibility that many initiatives achieved was considered an important strength for public campaigning, better outreach, and to improve the funding base.

DIVERSIFOOD case studies and outcomes confirmed the important role played by different actors within communities managing agrobiodiversity. These multi-actor networks are based on interactive and iterative processes to monitor their actions, usually with rules and norms socially agreed by the participants. The motivations to work together and embedding agrobiodiversity in their practices can be summarized in four points:

1. Using diversity in farming systems, especially in organic and low inputs ones, is a way to reduce the production costs and a strategy for coping with market price uncertainty and climate change. Moreover, starting new projects of PPB provide organic farmers the possibilities of breeding new adapted varieties that they cannot find in the seed market;

2. Creating alternative food systems based on diversity is seen as a strategy for regaining autonomy at local level with regard to large input suppliers and retailers;

3. Back to diversity in local food systems is a way to meet the new demands of citizens for healthy and quality food;

4. The actors involved in the initiatives see the limits and the impacts of the mainstream agricultural model. They would like to create alternative food systems, starting from seed to the plate, with an internal coherence all along the chain.

\subsection{Valorization of Biodiverse Food through Systemic Integration and Coherence}

The DIVERSIFOOD project adopted and developed a multi-actor, holistic, and systemic approach to investigate ways to enrich agrobiodiversity in food systems. It considered the valorization of biodiverse products in the market as an integral part of a broader, collective engagement, aimed at strengthening the entire production-consumption systems built on the values of agrobiodiversity. To that end, it analyzed the interactions developing within multi-actor networks including farmers and other practitioners directly involved, but also scientists, members of civil society organizations (CSOs), advisors, consumers, and, in some cases, public authorities. All the involved dimensions (technical, organizational, socio-cultural, legal, political) and their interconnections were considered as relevant in the development of these initiatives. The analyses also considered the influence from broader contexts 
of interaction and mobilization around agrobiodiversity enhancement and valorization. A common analytical framework was defined [89] to explore the different dimensions involved, distinguishing five critical areas of interaction:

- Mobilization of genetic resources: actions aimed at knowing and managing the landraces/varieties relevant for the local farming systems;

- Definition of specific product quality: actions to identify and codify the attributes of biodiverse products based on the selected varieties and methods of cultivation and processing;

- Marketing and communication: choices and tools to manage products in the market and convey values embodied in products and production systems;

- Interaction with other networks and projects: inter-connections with other projects/strategies, at local and wider scale;

- Effectiveness and sustainability of the initiative: capacity to contribute to agrobiodiversity enrichment, and to sustain existence over time.

This approach was applied to 11 cases studies, developed in eight European countries. Eight of these case studies focused on products from underutilized vegetables and grains, while the other three cases dealt with products from newly bred lines of bread wheat from PPB [90]. An important methodological aspect in applying the framework is that the study was built on close cooperation between the various researchers and actors involved in the case studies, according to multi-actor, and inter- and trans-disciplinary approaches adopted for the whole project [91]. Through an interactive and iterative process of mutual learning, this covered the development of the research questions and execution of the study as well as feedback-loops to comment on the findings.

In parallel to the analysis of the initiatives of valorization, information was gathered about the best strategies to communicate the added value of biodiverse products to consumers [92] and consumers' awareness of agrobiodiversity was assessed in a survey conducted in four European countries [93]. Focusing on a specific country (Finland), another study investigated a potential link between crop diversity and the diversity of food available to consumers in the market [94].

\subsubsection{Valorization of Biodiverse Food through Systemic Integration and Coherence}

- Collective learning and reshaping of the production systems

Despite all the differences among actors involved (i.e., farmers, processors, consumers, breeders), a certain coherence of vision, values, and knowledge is a crucial factor of success. A collaborative environment shows through the development of mutual trust, equality, and fairness, and this supports shared learning. Equally important is the involvement of other actors who can contribute to the creation of conducive conditions for (i) establishment/strengthening of relationships, (ii) access to information and its decoding, and (iii) interplay among different types of knowledge. In this regard, the key role played by facilitators and scientists and in some cases by local public officers often emerged in the case studies.

Within this collaborative environment the involved actors develop shared awareness and knowledge, common views, approaches, and goals. They are involved in collective processes of individual empowerment and engagement, which extend the space and potential of their actions, leading them to enter a system dimension and develop collective actions. This is particularly evident for farmers, who regain autonomy and competence in managing landraces and crops, interact with processors in different ways as well as acquire a new social position in the food system and, in some cases, a new political awareness.

These processes allow combining the different types of knowledge (experiential, scientific), fields of expertise (e.g., on technical, institutional, or legal aspects) and awareness (e.g., of political implications) held by the different actors. Such an enriched common pool of knowledge and competencies allows facing the technical, organizational, cultural, institutional, and legal challenges associated with the management and valorization of the biodiverse varieties, landraces, or heterogeneous genetic materials, as well as grasping new opportunities. 
This collective learning supports most of the processes involved in the valorization strategy. It is, for instance, at the root of the development of a common understanding of the distinctive characteristics of the biodiverse crops (i.e., adaptation, yield, agroecosystem performance) and of the special qualitative attributes of the derived food products (i.e., nutritional and nutraceutical values, processing quality, organoleptic properties), and associated cultural and ethical values related to the products and ecosystem services that agrobiodiversity provides and maintains over time [49].

The shared knowledge and vision in turn support the needed redefinition of the practices of farming and processing, as well as the ways to assess the crop and product quality. They also support the fine-tuning of suitable tools and arrangements within the supply chain (i.e., codes of practices, norms and rules, agreements, forms of protection from misappropriation), which are important to consolidate the new practices and the relationships among the actors. Together with the processes mentioned above, these processes contribute to the internal coherence, and consequently to the robustness and effectiveness of the collective reshaping of the production systems.

- Marketing biodiverse products and communication

The importance of internal coherence of knowledge and vision also emerges in the management of marketing and communication aspects. The initiatives that were analyzed showed clear differences in terms of marketing solutions, ranging from territorially embedded niche markets, in the forms of short chains, to working with conventional big retailers, aiming at upscaling the market of biodiverse products. A common critical factor is, however, the capacity to preserve the values embodied in the biodiverse products and to communicate them properly, thereby involving consumers in their appreciation. In longer chains, the capacity to define proper tools to manage the products on the market-such as agreements along the chain, voluntary standards, labels, trademarks, and logos-becomes crucial to overcome the limits coming from the lack of direct relationships between production and consumption. Where relationships are closer, particularly with consumers, the capacity to convey the special meanings of biodiverse products and to translate this cultural value in economic value and in durable consensus relies more on the quality of interactions built between the parties, and, sometimes, on the sense of community that develops around these production systems. However, also in these cases, logos and descriptive labels to accompany food products (or, earlier, the seeds) prove to be strategic to highlight and share the special values they embody. The potential of logos associated with certain production systems may also spill over into other channels. If a specific logo is used for consumer tasting events, farmers' markets or markets for seeds and planting materials, consumers may recognize the product in the supermarket if the same logo is used [92]. However, the analyses have shown that the EU quality labelling schemes (e.g., for geographical indications, traditional food, organic food) do not play a relevant role among these initiatives. People who belong to local networks engaged around biodiverse crops and foods perceive themselves as innovators and developers of new food systems, and look for more appropriate tools and strategies to promote products [92].

- Connection with other networks

The importance of interaction and associated collective learning and cooperation emerges once again when considering the connections established with other networks, both locally and in broader contexts. Interactions with other networks have proved to be important to strengthen the existing initiatives, catch new opportunities (such as research projects or innovations in the regulatory context), and further develop collective awareness, identity, and agency around agrobiodiversity management issues. All stages (from farming to marketing) and dimensions of the valorization strategies (from technical to cultural, legal, and political aspects) are involved. This results in supporting conditions for the consolidation and the sustainability of the initiatives aimed at reintroducing diversity in food systems, as well as for their diffusion in other contexts and, more in general, their impact on public opinion and culture of food. In a context of growing interest in agrobiodiversity by the agro-food industry and big retailers and with increasing openness by research institutes and policy makers, 
this broader collective dimension appears extremely meaningful, empowering actors/networks at the local scale, providing synergies as well as preventing losses of effectiveness.

- Creation of values

It is within this dimension of collective commitment, built on social capital and shared beliefs, visions, and goals, that the valorization shows to reach its full potential. The promotion of agrobiodiversity in the market results in involving the entire food system around the creation, understanding, and management of values. The core of the process is represented by the social processes underlying the development of a collective engagement around resources that are acknowledged for their social values and increasingly positioned within a broader framework of rights, seed and food sovereignty, and management of commons [41,95-97]. In this perspective, an additional potential of the strategies aimed at embedding diversity in local food systems is link to the broad meaning that the concept of diversity assumes. Agrobiodiversity management mobilizes and interrelates multiple, specific resources, which include biological and ecological, but also cultural and social diversity, leading to strategy building on the specific features of local socio-ecological systems.

\subsubsection{What Position on the Market and Perception and Role of Consumers}

- Perception of biodiverse products by consumers

Significant dynamics have emerged in relation to how biodiverse products are positioned in the market and are perceived by consumers, resulting in different but also evolving attitudes $[90,93]$. These products may (i) be attractive merely for health or organoleptic reasons, (ii) be also integrated into the local food traditions, thus identified with a place, or (iii) be more importantly linked to the local production system and the associated importance of the management of local genetic resources. Taste and quality attributes help positioning of a product in the market as taste and health are relevant for consumers. The second aspect is linked to an increasing consumers' interest in local and traditional food, preferred over industrial food. Both strategies, however, show the need that consumers develop a greater awareness of the deeper values of biodiverse products and of implications of agrobiodiversity conservation-enhancement. This could mean, for instance, being aware of the origin of varieties and their adaptation to the local agro-ecosystem and related local socio-cultural food habits. The third form of positioning refers to the embeddedness of biodiverse products in the social system that links seed savers, farmers, processors, consumers, researchers, and facilitators around the management of crop-food diversity. Here, the product quality covers social dimensions like those of 'community management/belonging' and 'seed/food sovereignty/autonomy' that the product stands for. This is a more challenging strategy implemented by some of the networks that were analyzed.

- Increased willingness of consumers by information

This progressively increasing engagement of consumers shows how they may play a role that goes beyond being mere recipients of valorization strategies. In addition to what emerges from the case studies [90], the specific survey that was conducted on consumers showed that, when informed, these are interested in biodiverse food and there is an increased willingness to pay for the values incorporated in the products [93]. This positive attitude fits the goals of valorization strategies as conceived in DIVERSIFOOD. Indeed, consumers are invited to develop greater awareness and responsibility, as well as sense of belonging to and willing to participate actively in collective strategies for reviving diversity and, through that, sustainability of food systems. 


\subsubsection{What Strategies for What Model of Development}

- A variegated approach to the form of development

The approach to biodiverse product quality is associated with that of the development model. Many of the cases studied reported ethical dilemmas in deciding how best to develop their supply without compromising their principles based on environmental sustainability, farmer empowerment, and embeddedness in local contexts and cultural heritage. In some of the cases, there is no interest in scaling up the business or in collaboration with larger actors in the market. There are, however, examples where a collaboration with retailers, based on strict rules, turned out to be supportive to genetically biodiverse crops [92]. Overall, most of the networks are rather interested in (i) improving the relationships with consumers and supporting them in their relation to food through education on the meaning and values of products (scaling deep), and/or (ii) sharing their experiences and allowing others to replicate them, locally or in other territories (scaling out). Other studies have documented this more variegated approach to the form of development when dealing with value-laden products [98].

All this shows a relevant finding of the research: there is not a one-size-fits-all approach for developing pathways and, consequently, for promotion strategies. More comprehensive and nuanced approaches are needed to better suit the motivations, values, visions, and goals on which the initiatives are founded, and the features of crop systems and product(s) that they want to promote [99].

- A local dimension

The case studies show, however, that the local dimension of business is a fundamental component of the development of biodiverse production systems and of the market valorization strategies. It facilitates the interactions among the chain actors around the management of the diverse genetic resources in the specific contexts and the cocreation and management of the specific quality of products. This is important to support farmers in entering the different logic that characterizes farming diverse varieties, facing the many challenges it implies and acquiring a more autonomous role. This is also in line with the DIVERSIFOOD approach, based on the specific interaction among genetic, environment, and social components (GxExS) [36,100,101], as well as on the development of on-farm and community-based management of genetic resources [102-104]), embedded in local contexts. Local value chains also facilitate interaction with consumers, communication of the special quality of the product, and identification of the origin of this quality in the features of the local production system and its genetic resources management. Involving consumers in a broader, collectively shared process of empowerment supports consumers' awareness raising and a potential stronger engagement in the local food systems and agrobiodiversity enhancement. This socially shared and contextualized growth of awareness and sense of responsibility make consumers' adhesion much more effective [105].

The local dimension also provides further modes of development. It can favor a growth of the production systems through an increase of the number and the type of actors involved. This includes farmers (already turned to organic/agroecological farming or aware of agrobiodiversity issues), processors, intermediate users (such as restaurants), retailers, and other traders. Moreover, the local dimension can favor the interaction with other societal developments carried out locally, opening up new opportunities.

\section{An Enabling Environment to Embed Diversity in Food Systems}

Stimulating the diversification of agriculture towards sustainable food systems is a complex process that requires several organizational, technical, and socio-economic advancements. DIVERSIFOOD has provided and optimized several steps of this process: the deployment of genetic resources from genebanks to farmers' field for testing, advancements in participatory plant breeding, better understanding of collective management of agrobiodiversity, a refined market valorization for biodiversity-based products, and a better description of the underlying social processes and multi-actor approaches. To scale out these outcomes and achievements, it is essential to understand the overall conducive conditions that would enable the wider agricultural and food system to undertake a more 
sustainable route for development. In this section, we highlight and discuss (i) how to integrate the management of seeds and knowledge in successful participatory breeding programs, (ii) how to overcome technical and regulatory bottlenecks, (iii) how to embed biodiversity-based innovation in broader models of food system development.

\subsection{Seeds, Data, and Breeding}

To foster a diversification of cropping and food systems through underutilized genetic resources, two aspects need to be ensured. First, there needs to be an adequate structure for genetic resources conservation and management, which has been extensively described in Section 3.3. Second, a knowledge base needs to be constituted and made available to make these genetic resources useful for use in cultivation, food systems, and for breeding. Thus, knowledge and seeds should be managed concomitantly within the network of actors.

Virtually every research on plant genetic resources produces a database. Existing PGR databases range between two extremes: on the one hand, centralized databases with generic, standardized phenotypic descriptions of genetic resources, which lack any specification of the potential contexts of use and related performance; on the other hand, locally maintained datasets, which generally end up being of limited utility and use. The 'siloed' structure of research datasets and lack of linkage between genetic resources data and e.g., the context where they were grown are recognized as major bottlenecks to research impact on crop diversification [106]. The DIVERSIFOOD Database [74] is a proof-of-concept of a repository of performance data to enable an interactive, analytic exploration of genetic resources performances in different trials, each with its pedo-climatic and socio-economic context and its objectives and resources, as resulting from participatory multi-actor approaches. Information repositories accounting for all information related to GxE interaction of plant genetic resources will be vital for successful diversification in cropping systems and breeding.

This is also in line with the new approach to conservation of plant genetic resources for food and agriculture (PGRFA), calling for a paradigm shift from biodiversity conservation to Community Agrobiodiversity Management (CAM). This approach aims to increase the overall diversity within farming systems, well beyond current approaches based on the conservation of a given level of diversity, e.g., given varieties or species. In fact, CAM includes not only traditional on-farm conservation activities (e.g., landraces in their environment) but also innovation and research (e.g., participatory plant breeding-PPB), seed swaps and sharing (e.g., through community seed banks), and the seed marketing (e.g., farm-based/local seed companies). In these processes, special attention should be paid to the social relationships among the different actors involved. Two elements appear to be important for their long-term sustainability and success: (i) the sharing of a vision, values, and beliefs among the actors involved; (ii) the role of facilitators/brokers played by advisors or other entities such as civil society organizations engaged in the agrobiodiversity issues. Both elements are paramount in terms of trust building, willingness to cooperate, sense of mutuality, and shared commitment. The lack of alignment around values and beliefs may generate divergences or conflicts in the ways in which the different actors, carriers of different knowledge and visions, interact.

As far as breeding is concerned, DIVERSIFOOD has advanced PPB strategies, in line with previous European projects (SOLIBAM-FP7 [107] and COBRA-Core Organic [108]), and has demonstrated how a panoply of breeding methods and tools can be applied to a broad range of crops and in very diverse contexts. The analysis of all the PPB programs yielded some general emerging threads:

1. Enlarging the diversity of germplasm sources, ranging from landraces to commercial varieties and breeding lines, to allow the further development of farmer varieties, variety mixtures, dynamic populations, and CCPs, using various methods;

2. Expanding the diversity and sources of data, and inclusiveness of the data collection process to involve farmers and processors using various techniques ranging from scorecards to molecular diversity assessments, nutritional grain quality testing, and digital image analysis; 
3. Innovative social organization around the breeding process, organized in a process of decisionmaking meetings, information-gathering interviews and focus groups, joint field and lab visits, trainings and produce evaluation;

4. Legislative and regulatory issues, to recognize the role of farmers' collective organization in the creation and management of plant genetic resources and to improve the process of seeds registration.

As a result, these PPB experiences proved to be a trigger of empowerment. In fact, they reinforced collective decision making, created new farmers-researchers partnerships, and expanded the range of technical tools for breeding and evaluation available to communities [77].

\subsection{Overcoming Technical and Regulatory Bottlenecks}

While it is now commonly acknowledged that farmers have a role in the maintenance and development of crop genetic diversity, other supply chain players, such as processors, traders, as well as consumers, have a crucial role to play [109]. To enlarge such multi-actor networks, understanding the barriers and opportunities that affect the sustainable use of crop genetic diversity becomes crucial. DIVERSIFOOD identified constraints and enabling factors shaping the agri-food systems related to (1) crop (such as breeding system, plant phenology, and architecture), (2) socio-cultural aspects (labor organization, taste preferences, learning processes, and change of attitudes), (3) economic aspects (value distribution along the chain, affordability), (4) agro-ecological elements (climate, soils, farming system), (5) organizational-institutional elements (forms of coordination among actors, norms), and (6) legal-political aspects (regulatory frames, tools for genetic material protection, incentives). This wide range of aspects are moreover interconnected, generating a complexity that can hardly be understood unless holistic, multi-actor approaches are adopted. To this end, DIVERSIFOOD has taken into account four key components of this approach: (i) the level of participation and democracy, i.e., actor involvement in the various research steps, (ii) the level of trans-disciplinarity, i.e., the knowledge resources mobilized and their degree of integration, (iii) the multi-dimensionality and systemic approach, i.e., crops, technical, socio-cultural, economic, organizational-institutional, legal-political domains, and associated interconnections, and (iv) the reflexivity, i.e., level and modes of evaluation of achievements, in relation to coherence and effectiveness of actions.

When these concepts are applied to plant breeding, landraces appear not anymore as 'genetic resources', but rather as the result of ongoing evolutionary processes at local and/or regional level, which are shaped by agro-ecological, socio-cultural, economic, and political dimensions. Hence, landraces cannot be static but are dynamic, representing local/regional change over time. On the use and definition of new landraces for the future of agriculture, scholars have different views. For example, Casañas and colleagues [110], whilst recognizing that (i) "the term 'landrace' encompasses a range of different concepts that have varied over time depending on prevailing trends in the use and conservation of genetic resources" and that (ii) "nowadays there is an increasingly commercial message promoting that landraces are generally endowed with superior nutritional and sensory properties", have proposed to extend the concept of landraces, beyond their currently recognized socio-ecological value, and to consider landraces as a reservoir of genes, to study their potential and correct their defects with all available technologies (including biotechnologies). In fact, landraces, their origin, their genetic structures and the methods used to obtain them are strongly connected [111] and interpreting them as "reservoir of genes" can be dangerously limiting. DIVERSIFOOD calls for greater emphasis on supporting conditions to promote this process of on-farm evolution, supported by participatory and decentralized research. Conditions that, according to the last State of the World of Biodiversity published by the FAO in 2019, are disappearing at an alarming rate: "biodiverse agricultural landscapes in which cultivated land is interspersed with uncultivated areas such as woodlands, pastures and wetlands have been, or are being, replaced by large areas of monoculture farmed using large quantities of external inputs such as pesticides, mineral fertilizers and fossil fuels" [8].

DIVERSIFOOD plant breeding concepts are rooted into the organic principles: (1) Principle of Health: Healthy soil, plants, animals, humans for a healthy planet; (2) Principle of Ecology: Emulating 
and sustaining natural systems; (3) Principle of Fairness. Equity, respect, and justice for all living beings and (4) Principle of Care, for the generations to come. These principles prevent the use of any kind of biotechnology that violates these principles. Landraces and new diverse farmers' populations are particularly adapted to sustain diverse agroecosystems. As such, we proposed a consistent framework to the sustainable use of genetic diversity, with special emphasis on organic food systems and in the perspective of agroecology transition. In fact, thanks to on-farm breeding in organic conditions and community seed management, plants have the ability to evolve and to adapt generation after generation. New diversity is thereby developed by relying only on natural methods manageable by farmers (crossings and mixtures) whilst respecting the natural biological barriers between species. The resulting farmer's or peasant's variety differ from the common 'labels' of heirloom, traditional variety, local variety, in their contemporaneity and novelty. They are bred from all forms of genetic resources by farmers, mainly organic farmers, respecting their natural reproduction system and using plant breeding methods in line with the IFOAM principles [75,112]. These varieties are mainly managed collectively thanks to Community Seed Banks [113] or farmer cooperatives allowing farmer autonomy and empowerment.

\subsection{The Need for Appropriate Policies}

Besides the technical and methodological bases for participatory plant breeding and community agrobiodiversity management, the ultimate need is to create an enabling external environment to support food systems in their efforts to enhance agrobiodiversity [114]. In first instance, conducive policies for seed production and circulation are needed. Current seed laws and policies are not designed to promote diversity in agricultural systems and thus hinder food diversity $[36,82,115,116]$. In fact, 'heterogeneous materials', which would allow increasing crop genetic diversity, do not have yet a valid and clear legal status, and thus cannot officially be marketed as seeds.

More in general, conducive policies are needed for all the aspects involved and should aim at creating favorable conditions for the various actors to play an active role to contribute to coherent collective strategies of enhancement of agrobiodiversity [100,114]. In a broader multi-actor perspective, this relates to the role of (i) breeders, whose activity should be deeply reoriented to achieve the multiple goals of agrobiodiversity; (ii) farmers and other supply chain actors, who need coherent policy interventions and proper forms of support in such a challenging reorganization of their activities; (iii) researchers, who should be encouraged and supported in using participatory and inter- and transdisciplinary approaches; (iv) facilitators, whose role proves to be crucial in bridging diverse knowledges and fields of action but is still not sufficiently rewarded; (v) consumers, who need to acquire awareness about more sustainable food systems, and to develop a common sense of responsibility; and (vi) regional/local public authorities, who need to acknowledge their role in steering innovation, and how governance shapes food systems.

Such an empowering process should build on the potential of the interactive network dimension and of locally adapted solutions. This is in line with the model adopted by EU policies for innovation (EIP-AGRI), stressing the role of networks and interactions. DIVERSIFOOD has given ample examples of the effectiveness of this approach, uncovering the mechanisms underlying these processes and the ways to support them.

By supporting grassroots, localized initiatives and connecting them with scientific knowledge, another significant contribution could come from the development of an informed public dialogue about society's responsibility to increase and embed agrobiodiversity in the food systems, considering agrobiodiversity (and consequently seeds) as a crucial commons, to be properly managed to strengthen both ecological and societal resilience. In addition, also in this case, the emerging discourse looking at food-related issues in this perspective appears encouraging [41]. 


\section{Conclusions}

Whilst broadening in the uses of genetic diversity for a more sustainable agricultural development is widely recognized, there is still little clarity about what shape such development should take. Agroecology offers a perspective of an all-embracing change in agricultural and food systems going beyond current technical innovations. In fact, it is only by embedding agrobiodiversity in an overall rethinking of the ecological, technological, socio-economic, and political aspects of agriculture that sustainable food systems can ultimately be developed and rooted. The DIVERSIFOOD project offered a proof-of-concept of such changes at multiple levels of the food system, including the deployment of genetic resources in farmers' field, adoption of participatory plant breeding, collective management of agrobiodiversity at community level, and better understanding of the functioning of local, short supply chains of biodiverse products that can make the agroecological transition financially viable. Furthermore, DIVERSIFOOD has gone beyond merely implementing a multi-actor approach for a smoother application or dissemination of scientific results: it has rather prioritized a democratization of science and a reconnection between farmers' and citizens' initiatives and research through a collective learning and innovation process.

Author Contributions: All the authors contributed to the writing of this review according to the tasks they performed during the project. V.B. coordinated the project, reviewed, and edited the overall text. All authors have read and agreed to the published version of the manuscript.

Funding: This research was funded by the European Union's Horizon 2020 research and innovation programme under grant agreement No 633571 (DIVERSIFOOD project) for the period 2015-2019.

Acknowledgments: The authors gratefully acknowledge the participation of all the partners of the EU project DIVERSIFOOD (Embedding crop diversity and networking for local high quality food systems) in all the steps of the project (conception, methodologies, tools, data collection, and analysis) and which are presented in this project review. Authors would like to thank the anonymous reviewers for the valuable comments to improve the manuscript.

Conflicts of Interest: The authors declare no conflict of interest.

\section{Appendix A}

Table A1. PPB Strategies. Methods used by the partners that contributed for the development of PPB.

\begin{tabular}{|c|c|c|c|c|c|}
\hline \multirow{2}{*}{ Partner } & \multirow{2}{*}{ Strategy } & \multicolumn{4}{|c|}{ Methods } \\
\hline & & (1) Genetic Resources & (2) Techniques & (3) Social & (4) Legislation \\
\hline $\begin{array}{l}\text { INRA and } \\
\text { RSP }\end{array}$ & $\begin{array}{l}\text { Participatory } \\
\text { breeding of wheat } \\
\text { populations and } \\
\text { mixtures with on } \\
\text { farm evaluation and } \\
\text { selection and } \\
\text { collective } \\
\text { decision-making. }\end{array}$ & $\begin{array}{l}\text { Landraces and lines } \\
\text { used as such or within } \\
\text { mixtures or crosses }\end{array}$ & $\begin{array}{l}\text { Regional and satellite farms experimental } \\
\text { design with hierarchical Bayesian model to } \\
\text { analyse using the R package PPBStats. } \\
\text { Comparison of selection practices of } \\
\text { mixtures of populations. }\end{array}$ & $\begin{array}{l}\text { Regular meetings to } \\
\text { present results and } \\
\text { take decisions. Fields } \\
\text { visits. Training of } \\
\text { farmers/facilitators. }\end{array}$ & $\begin{array}{l}\text { Contributed to } \\
\text { the recognition } \\
\text { of the role of } \\
\text { farmers' } \\
\text { organisations } \\
\text { in the creation } \\
\text { and } \\
\text { maintenance of } \\
\text { crops genetic } \\
\text { resources. }\end{array}$ \\
\hline $\begin{array}{l}\text { INRA and } \\
\text { ITAB }\end{array}$ & $\begin{array}{l}\text { Looking for answers } \\
\text { to farmers' question } \\
\text { "differences between } \\
\text { CCP and dynamic } \\
\text { populations of } \\
\text { wheat", in a } \\
\text { partnership } \\
\text { relationship between } \\
\text { farmers and } \\
\text { researchers }\end{array}$ & $\begin{array}{l}\text { Populations cultivated at } \\
\text { a farmer and used to } \\
\text { create a dynamic } \\
\text { mixture and a CCP }\end{array}$ & $\begin{array}{l}\text { Involving farmers and bakers in the } \\
\text { selection and evaluation (processing) of the } \\
\text { populations }\end{array}$ & $\begin{array}{l}\text { Informal relationship } \\
\text { (beginning of the } \\
\text { process) }\end{array}$ & \\
\hline LBI & $\begin{array}{l}\text { Participatory } \\
\text { breeding to improve } \\
\text { wheat populations }\end{array}$ & $\begin{array}{l}\text { Spring wheat population } \\
\text { from Dottenfelderhof }\end{array}$ & $\begin{array}{l}\text { Farmers and bakers were involved in the } \\
\text { selection and evaluation }\end{array}$ & $\begin{array}{l}\text { Informal and some } \\
\text { meetings to discuss } \\
\text { results and follow-up } \\
\text { steps }\end{array}$ & \\
\hline
\end{tabular}


Table A1. Cont.

(1) Decision tools for selection of both germplasm and locations to potentiate certain components (e.g. tocopherols)

(2) Field evaluation of chlorophyll fluorescence analysis (Fv/Fm efficiency of Photosystem II- and Performance Index (PI),-OJIP test); Field evaluation of leaf/canopy temperature (Thermal Imaging) Field evaluation of gas exchange parameters: Leaf transpiration, parameters: Leaf transpiration, photosynthesis, under saturating light (Infrared gas analyser); Leaf relative water content calculated using leaf discs collected at field trial; Field evaluation of plant growth, flowering time, biomass and yield;

(3) Screening for disease resistance to mycotoxins in maize OPV;

OPV sensorial analyses tests are being prepared presently (March 2019)

(3) maize inbreed lin
2 focus groups, 2

stakeholders meeting,

\# interviews

(4) Molecular diversity assessment and nutritional grain quality evaluation

(5) Genome wide association studies on maize quality traits.

\begin{tabular}{|c|c|c|c|c|c|}
\hline CSIC & $\begin{array}{l}\text { Comparison of self } \\
\text { vs open-pollination } \\
\text { breeding approaches } \\
\text { in yield and yield } \\
\text { determinants }\end{array}$ & $\begin{array}{l}\text { Three populations in two } \\
\text { versions open-pollinated } \\
\text { vs. three generations of } \\
\text { selfing }\end{array}$ & $\begin{array}{l}\text { Digital Image Analysis. Descriptors. } \\
\text { ANOVAs and Multivariate analysis: } \\
\text { Principal Components and Discriminant }\end{array}$ & $\begin{array}{l}\text { Informal farmer } \\
\text { meetings and } \\
\text { collaboration in a } \\
\text { multi-actor } \\
\text { symposium }\end{array}$ & \\
\hline $\begin{array}{l}\text { RSP and } \\
\text { ITAB }\end{array}$ & $\begin{array}{l}\text { Multi-actors' } \\
\text { approach-building a } \\
\text { research community } \\
\text { in order to improve } \\
\text { co-evolution } \\
\text { mechanisms between } \\
\text { humans-tomatoes } \\
\text { varieties and natural } \\
\text { environments }\end{array}$ & $\begin{array}{l}\text { Practitioners' tomatoes } \\
\text { populations }\end{array}$ & $\begin{array}{l}\text { Scorecards for practitioners on farm } \\
\text { observation, PPBstats R package. }\end{array}$ & $\begin{array}{l}\text { Stakeholders meeting } \\
\text { twice a year, focus } \\
\text { groups phone calls, } \\
\text { steering committee } \\
\text { phone calls. Building } \\
\text { of a research } \\
\text { community. }\end{array}$ & \\
\hline RAS & $\begin{array}{l}\text { Building a research } \\
\text { community, } \\
\text { developing evolving } \\
\text { populations of wheat } \\
\text { and tomato }\end{array}$ & $\begin{array}{l}\text { Local varieties of wheat } \\
\text { and public gene banks so } \\
\text { as RAS community seed } \\
\text { bank }\end{array}$ & $\begin{array}{l}\text { Mix the most important varieties of wheat } \\
\text { and tomato. Agronomic data were collected }\end{array}$ & $\begin{array}{l}\text { Farmers prepared the } \\
\text { trials, collected the } \\
\text { data and collaborated } \\
\text { in the elaboration of } \\
\text { the protocols. In order } \\
\text { to train them to carry } \\
\text { on with the process } \\
\text { RAS organised several } \\
\text { meetings and farm } \\
\text { visits. }\end{array}$ & \\
\hline PSR & $\begin{array}{l}\text { Improve rare } \\
\text { vegetable types by } \\
\text { crossing old varieties } \\
\text { with commercial } \\
\text { varieties of known } \\
\text { target qualities, and } \\
\text { maintain or improve } \\
\text { taste qualities by } \\
\text { involving chefs and } \\
\text { other stakeholders }\end{array}$ & $\begin{array}{l}\text { Old varieties and } \\
\text { landraces collected and } \\
\text { conserved within the } \\
\text { PSR network }\end{array}$ & $\begin{array}{l}\text { Crossbreeding with several combinations, } \\
\text { reciprocal harvest of seeds, start new } \\
\text { population lines out of each harvested lot } \\
\text { and select each population over several } \\
\text { generations according to breeding targets. } \\
\text { Brix content measurements allows positive } \\
\text { selection within each generation. } \\
\text { Organoleptic selection of the best lines only } \\
\text { in hindsight. }\end{array}$ & $\begin{array}{l}\text { Stakeholder meetings } \\
\text { to assess the resulting } \\
\text { population lines, } \\
\text { involvement of chefs } \\
\text { for organoleptic } \\
\text { evaluation. }\end{array}$ & $\begin{array}{c}\text { Registration as } \\
\text { «Niche } \\
\text { Varieties» in } \\
\text { Switzerland as } \\
\text { soon as } \\
\text { professional } \\
\text { production is } \\
\text { promising. }\end{array}$ \\
\hline $\begin{array}{l}\text { Arche } \\
\text { Noah }\end{array}$ & $\begin{array}{l}\text { Participatory } \\
\text { research and } \\
\text { breeding to improve } \\
\text { colourful tomatoes } \\
\text { for direct marketing } \\
\text { (decentralised } \\
\text { individual breeding } \\
\text { programs) }\end{array}$ & $\begin{array}{l}\text { Divers: Accessions from } \\
\text { the ARCHE NOAH seed } \\
\text { archive and other gene } \\
\text { banks, commercial } \\
\text { varieties, } \\
\text { landraces/heirloom } \\
\text { varieties, breeding lines }\end{array}$ & $\begin{array}{l}\text { Pedigree selection and back-cross breeding } \\
\text { programs. Primary, the site-specific aims } \\
\text { indicate the selection techniques. However, } \\
\text { one focus across several locations has been } \\
\text { laid on leaf mould resistance. }\end{array}$ & $\begin{array}{l}\text { Internal: Annual } \\
\text { working group } \\
\text { meetings, field days, } \\
\text { workshops, product } \\
\quad \text { tastings. } \\
\text { External: interviews } \\
\text { with stakeholders }\end{array}$ & \\
\hline
\end{tabular}




\section{References}

1. Wezel, A.; Bellon, S. Agroecology as a science, a movement and a practice. A review. Agron. Sustain. Dev. 2009, 29, 503-515. [CrossRef]

2. Yapa, L. What Are Improved Seeds? An Epistemology of the Green Revolution. Econ. Geogr. 1993, 63, $254-273$. [CrossRef]

3. Tittonell, P. Ecological intensification of agriculture-sustainable by nature. Env. Sustain. 2014, 8, 53-61. [CrossRef]

4. Gliessman, S. Transforming food systems with agroecology. Agroecol. Sustain. Food Syst. 2016, 40, 187-189. [CrossRef]

5. Duru, M.; Therond, O. Designing agroecological transitions: A review. Agron. Sustain. Dev. 2019, 35, $1237-1257$. [CrossRef]

6. Levidow., L.; Birch, K. Divergent paradigms of european agro-food innovation: The knowledge-based bio-economy (KBBE) as an R\&D agenda. Sci. Technol. Hum. Value 2012, 38, 94-125. [CrossRef]

7. Demeulaneare, E.; Goldringer, I. Seeds and an agroecological transition: Farmers' initiatives and participatory plant breeding as breakthrough innovation. Nat. Sci. Sociétés 2017, 4, 55-59. [CrossRef]

8. FAO. The State of the World's Biodiversity for Food and Agriculture; Bélanger, J., Pilling, D., Eds.; FAO Commission on Genetic Resources for Food and Agriculture Assessments: Rome, Italy, 2019; p. 572. Available online: http://www.fao.org/3/CA3129EN/CA3129EN.pdf (accessed on 16 January 2020).

9. McIntyre, B.D.; Herren, H.R.; Wakhungu, J.; Watson, R.T. Agriculture at a Crossroads: The Global Report. IAASTD (The International Assessment of Agricultural Knowledge, Science and Technology for Development) 2009. Global Report. Synthesis Report; Island Press: Washington, DC, USA, 2009; p. 590. ISBN 9781597265386.

10. IPES-Food. From Uniformity to Diversity: A Paradigm Shift from Industrial Agriculture to Diversified Agroecological Systems. International Panel of Experts on Sustainable Food systems. 2016. Available online: www.ipes-food.org (accessed on 16 January 2020).

11. FAO. Agricultural Biodiversity, Multifunctional Character of Agriculture and Land Conference, Background Paper 1. Maastricht, The Netherlands. 1999. Available online: http://www.fao.org/mfcal/pdf/bp_1_agb.pdf (accessed on 16 January 2020).

12. The EIP-Agri is Part of EU's Growth Strategy for This Decade. Available online: https://ec.europa.eu/eip/ agriculture/en/about/eip-agri-part-eu\%E2\%80\%99s-growth-strategy-decade (accessed on 18 October 2019).

13. Padulosi, S.; Hodgkin, T.; Williams, J.T.; Haq, N. Underutilized Crops: Trends, Challenges and Opportunities in the 21st Century. In Managing Plant Genetic Diversity, Proceedings of the Biodiversity International Conference, Kuala Lumpur, Malaysia, June 2000; Engels, J.M.M., Ramanatha, R.V.., Brown, A.H.D., Jackson, M.T., Eds.; CABI Publishing: New York, NY, USA, 2001; pp. 323-338.

14. FAO. The State of the World's Plant. Genetic Resources for Food and Agriculture; FAO: Rome, Italy, 1997; Available online: http://ftp.fao.org/docrep/fao/meeting/015/w7324e.pdf (accessed on 16 January 2020).

15. Engels, J.M.M. Plant Genetic Resources Management and Conservation Strategies: Problems and Progress. Acta Hort. ISHS 2004, 634, 113-125. [CrossRef]

16. Bonneuil, C. Seeing nature as a 'universal store of genes': How biological diversity became 'genetic resources'. Stud. Hist. Philos. Biol. Biomed. Sci. 2019, 75, 1-14. [CrossRef]

17. Bocci, R. D1.2: Report Presenting the EU Context. 2019. DYNAVERSITY. Available online: http://dynaversity. eu/project/\#deliverables (accessed on 16 January 2020).

18. FAO. Vingt-deuxième Conférence FAO (Résolution 8/83) 5-23 November; FAO: Rome, Italy, 1983.

19. Bonneuil., C.; Fenzi., M. Des ressources génétiques à la biodiversité cultivée. La carrière d'un problème public mondial. Rev. D'anthropologie Connaiss. 2011, 5, 206-233. [CrossRef]

20. Altieri, M.A.; Merrick, L.C. In situ Conservation of Crop Genetic Resources through Maintenance of Traditional Farming Systems. Econ. Bot. 1987, 41, 86-96. [CrossRef]

21. Weise, S.; Oppermann, M. EURISCO: The European Search Catalogue for Plant Genetic Resources. Nucleic Acids Res. 2017, 45, 1003-1008. [CrossRef] [PubMed]

22. ECPGR. ECPGR Concept for On-Farm. Conservation and Management of Plant. Genetic Resources for Food and Agriculture; European Cooperative Programme for Plant Genetic Resources: Rome, Italy, 2017; Available online: http://www.ecpgr.cgiar.org/fileadmin/bioversity/publications/pdfs/ECPGR_Concept_for_on_farm_ final_05_05_2017_bis.pdf (accessed on 16 January 2020).

23. Preparatory Actions. Available online: https://www.geneticresources.eu/the-study/ (accessed on 18 October 2019). 
24. Zoom Sur le Gwell. Available online: https://bretonnepienoir.com/des-produits-naturels-gouteux-et-sainsissus-d-elevages-en-plein-air/zoom-sur-le-gwell/ (accessed on 16 January 2020).

25. Lammerts van Bueren, E.T.; Struik, P.C.; Tiemens-Hulscher, M.; Jacobsen, E. Concepts of Intrinsic Value and Integrity of Plants in Organic Plant Breeding and Propagation. Crop. Sci. 2003, 43, 1922-1929. [CrossRef]

26. Nuijten, E.; Messmer, M.M.; Lammerts van Bueren, E.T. Concepts and Strategies of Organic Plant Breeding in Light of Novel Breeding Techniques. Sustainability 2017, 9, 18. [CrossRef]

27. Rey, F.; Sinoir, N. Organic seeds and plant breeding: Stakeholders' uses and expectations-French inputs on vegetables. Int. Symp. Org. Greenh. Hortic. 2013, 1041, 133-139. [CrossRef]

28. Van Bueren, E.L.; Jones, S.S. The need to breed crop varieties suitable for organic farming, using wheat, tomato and broccoli as examples: A review. NJAS Wagening. J. Life Sci. 2011, 58, 193-205. [CrossRef]

29. Lammerts van Bueren, E.T.; Struik, P.C.; van Eekeren, N.; Nuijten, E. Towards resilience through systems-based plant breeding. A review. Agron. Sustain. Dev. 2018, 38, 42. [CrossRef]

30. Goldringer, I.; Rivière, P. Methods and Tools for Decentralized on Farm Breeding. Booklet\#3 2018, DIVERSIFOOD. Available online: http:/www.diversifood.eu/wp-content/uploads/2018/12/booklet3_decentralized_on_farm_ breeding_BAT_web_A4_2.pdf (accessed on 16 January 2020).

31. Döring, T.F.; Knapp, S.; Kovacs, G.; Murphy, K.; Wolfe, M.S. Evolutionary plant breeding in cereals-into a new era. Sustainability 2011, 3, 1944-1971. [CrossRef]

32. Vernooy, R.; Shrestha, P.; Bhuwon Sthapit, B. Community Seed Banks, origins, evolution and prospects. In Agricultural Biodiversity; Earthscan Routledge: London, UK, 2015; p. 270. Available online: https://www.bioversityinternational.org/ e-library/publications/detail/community-seed-banks-origins-evolution-and-prospects/ (accessed on 16 January 2020).

33. Shrestha, P.; Vernooy, R.; Chaudhary, P. Community Seed Banks in Nepal: Past, Present, Future. In Proceedings of the National Workshop, LI-BIRD/USC Canada Asia/Oxfam/The Development Fund/IFAD/Bioversity International, Pokhara, Nepal, 14-15 June 2012.

34. Dwivedi, S.L.; Lammerts van Bueren, E.T. Diversifying food systems in the pursuit of sustainable food production and healthy diets. Trends Plant. Sci. 2017, 22, 842-856. [CrossRef]

35. Hufford, M.B.; Berny, M. Crop Biodiversity: An Unfinished Magnum Opus of Nature. Annu. Rev. Plant. Biol. 2019, 70, 727-751. [CrossRef]

36. Lammerts van Bueren, E.T.; Struik, P.C. Towards resilience through systems-based plant breeding. A review. Agron. Sustain. Dev. 2018, 5, 38-42. [CrossRef] [PubMed]

37. Zimmerer, K.S.; de Haan, S. The biodiversity of food and agriculture (Agrobiodiversity) in the Anthropocene. Research advances and conceptual framework. Anthropocene 2019, 25, 1-16. [CrossRef]

38. FAO. Proceedings of the International Scientific Symposium: Biodiversity and Sustainable Diets; United Against Hunger; FAO: Rome, Italy, 2011.

39. Allen, T.; Prosperi, P. Agricultural biodiversity, social-ecological systems and sustainable diets. Nutr. Soc. 2014, 73, 498-508. [CrossRef] [PubMed]

40. Pascual, U.; Muradian, R. Exploring the links between equity and efficiency in Payments for Environmental Services: A conceptual approach. Ecol. Econ. 2010, 69, 1237-1244. [CrossRef]

41. Vivero-Pol, J.L.; Ferrando, T. Handbook of Food as a Commons, 1st ed.; Routledge: Abingdon, UK, 2019.

42. Gruère, G.P.; Giuliani, A. Marketing underutilized plant species for the benefit of the poor: A conceptual framework. In Agrobiodiversity Conservation and Economic Development; Kontoleon, A., Pasqual, U., Eds.; Routledge: Abingdon, UK, 2009; pp. 73-87.

43. Hermann, M.; Bernet, T. The transition of maca from neglect to marketprominence: Lessons for improving use strategies and market chains of minorcrops. In Agricultural Biodiversity and Livelihoods Discussion Papers 1; Bioversity International: Rome, Italy, 2009.

44. Kruijssen, F. Collective action for small-scale producers of agricultural biodiversity products. Food Policy 2009, 34, 46-52. [CrossRef]

45. Krishna, V.V.; Pascual, U. Assessing the potential of labeling schemes for insitu landrace conservation: An example from India. Environ. Dev. Econ. 2010, 15, 127-151. [CrossRef]

46. Gautam, G. Tar analysis in syngas derived from pelletized biomass in a commercial stratified downdraft gasifier. BioResources 2011, 6, 4652-4661.

47. Klerkx, L.; Van Mierlo, B. Evolution of systems approaches to agricultural innovation: Concepts, analysis and interventions. In Farming Systems Research into the 21st Century: The New Dynamic; Darnhofer, I., Gibbon, D., Eds.; Springer: Dordrecht, The Netherlands, 2012; pp. 457-483. 
48. Koelen, M.; Das, E. Social learning: A construction of reality. In Wheelbarrows Full of Frogs: Social Learning in Rural Resource Management; Leeuwis, C., Pyburn, R., Röling, N.G., Eds.; Van Gorcum Ltd.: Assen, The Netherlands, 2002.

49. Brunori, G.; Rossi, A. A Comprehensive and participatory approach to the valorisation of biodiverse products. In Food Diversity between Rights, Duties and Autonomies. Legal Perspectives for a Scientific Cultural and Social Debate on the Right to Food and Agroecology; Isoni, A., Troisi, M., Eds.; LITES, Springer Cham: Basel, The Netherlands, 2018; Volume 2.

50. Rossi, A.; Bocci, R. The Transformative Potential of Social Innovation. The case of wheat and bread value chain in Tuscany. Int. J. Sociol. Agric. Food 2018, 24, 431-448.

51. Costanzo, A. Underutilised Crops. Innovation Factsheet no. 4 2017, DIVERSIFOOD. Available online: http: //www.diversifood.eu/wp-content/uploads/2018/06/Diversifood_IF4_Underutilised_Crops.pdf (accessed on 16 January 2020).

52. IPGRI. Neglected and Underutilized Plant. Species: Strategic Action Plan. of the International Plant. Genetic Resources Institute; International Plant Genetic Resources Institute: Rome, Italy, 2002; Available online: https: //www.unscn.org/layout/modules/resources/files/Neglected_and_Underutilized_Plant_Species.pdf (accessed on 16 January 2020).

53. Anonymous. Cordoba Declaration on Promising Crops for the XXI Century. In Proceedings of the International Seminar on Traditional and New Crops to Meet the Challenges of the XXI Century, Cordoba, Spain, 10-13 December 2012.

54. Anonymous. Background Document. In Proceedings of the International Seminar on Traditional and New Crops to Meet the Challenges of the XXI Century, Cordoba, Spain, 10-13 December 2012.

55. Kahane, R.; Hodgkin, T.; Jaenicke, H.; Hoogendoorn, C.; Hermann, M.; Keatinge, J.D.H.; d'Arros Hughes, J.; Padulosi, S.; Looney, N. Agrobiodiversity for food security, health and income. Agron. Sustain. Dev. 2013, 33, 671-693. [CrossRef]

56. Pretty, J. Some Benefits and Drawbacks of Local Food Systems; Briefing Note for TVU, Sustain AgriFood Networ: Essex, UK, 2001.

57. Esquinas-Alcázar, J. Protecting crop genetic diversity for food security: Political, ethical and technical challenges. Nat. Rev. Genet. 2005, 6, 946-953. [CrossRef]

58. Zeven, A.C. Classification of landraces and improved cultivars of rivet wheat (Triticum turgidum) and bread wheat (T. aestivum) from Great Britain and described in 1934. Euphytica 1990, 47, 249. [CrossRef]

59. Chable, V. The Rivet Wheat. Innov. Factsheet No. 5. 2018. DIVERSIFOOD. Available online: http://www. diversifood.eu/wp-content/uploads/2018/06/Diversifood_innovation_factsheet5-Rivet-Wheat.pdf (accessed on 16 January 2020).

60. Daurelle, N.; Maréchal, G.; Leprêtre, F.E.; Florent Mercier, F.; Chable, V. Multi-actor research for the renewal of minor cereals in the Western part of France. In Proceedings of the Organic Seed Growers Conference, Corvallis, OR, USA, 14-17 February 2018; Hubbard, K., Ed.; Organic Seed Alliance: Port Townsend, WA, USA, 2018; Volume 115, pp. 16-19.

61. Hufford, M.B.; Mier y Teran, J.C.; Gepts, P. Crop Biodiversity: An Unfinished Magnum Opus of Nature. Annu. Rev. Plant. Biol. 2019, 70, 727-751. [CrossRef] [PubMed]

62. Leakey, R.R.B.; Weber, J.C. Tree domestication in agroforestry: Progress in the second decade. In Multifunctional Agriculture-Achieving Sustainable Development in Africa, 1st ed.; Nair, P., Garrity, D., Eds.; Springer: Dordrecht, The Netherlands, 2012; Volume 9.

63. Khoury, C.K.; Achicanoy, H.A. Origins of Food Crops Connect Countries Worldwide. Proc. R. Soc. B 2016. Available online: https://royalsocietypublishing.org/doi/full/10.1098/rspb.2016.0792 (accessed on 16 January 2020). [CrossRef]

64. Kell, S.; Rosenfeld, A. Benefits of Non-Traditional Crops Grown by Small Scale Growers in the Midlands; Garden Organic: Coventry, UK, 2013.

65. Doring, T.; Knapp, S. Evolutionary breeding of cereals: Into a new era. Sustainability 2011, 3, $1944-1971$. [CrossRef]

66. Bartha, B. Landrace Tomatoes in Hungary. Innovation Factsheet no. 15. 2018. DIVERSIFOOD. Available online: http: //www.diversifood.eu/wp-content/uploads/2018/11/Diversifood_innovation_factsheet_15_tomato.pdf (accessed on 16 January 2020). 
67. Alves, M.L.; Belo, M.; Carbas, B.; Brites, C.; Paulo, M.; Mendes Moreira, P.; Vaz Patto, M.C. Long term on-farm participatory maize breeding by stratified mass selection retains molecular diversity while improving agronomic performance. Evol. Appl. 2018, 11, 254-270. [CrossRef]

68. Chable, V. Buckwheat. Innov. Factsheet No. 6. 2018. DIVERSIFOOD. Available online: http://www.diversifood. eu/wp-content/uploads/2018/11/Diversifood_innovation_factsheet_8.pdf (accessed on 16 January 2020).

69. Costanzo, A.; Serpolay, E. A Guide to Participatory Experimentation with Underutilised Genetic Resources. Bookl. \#2. 2019. DIVERSIFOOD. Available online: http://www.diversifood.eu/wp-content/uploads/2018/06/ Diversifood_innovation_factsheet2_VarietiesPopulations.pdf (accessed on 16 January 2020).

70. Kavadia, A.; Omirou, M.; Fasoula, D.; Trajanoski, S.; Andreou, E.; Ioannides, I.M. Genotype and soil water availability shape the composition of AMF communities at chickpea early growth stages. Appl. Soil Eco. 2019. [CrossRef]

71. Costanzo, A.; Amos, D.C.; Dinelli, G.; Sferrazza, R.E.; Accorsi, G.; Negri, L.; Bosi, S. Performance and Nutritional Properties of Einkorn, Emmer and Rivet Wheat in Response to Different Rotational Position and Soil Tillage. Sustainability 2019, 11, 6304. [CrossRef]

72. Ceccarelli, S. Adaptation to low/high input cultivation. Euphytica 1996, 92, 203-214. [CrossRef]

73. Desclaux, D.; Nolot, J.M. Changes in the Concept of Genotype X Environment Interactions to Fit Agriculture Diversification and Decentralized Participatory Plant Breeding: Pluridisciplinary Point of View. Euphytica 2008, 163, 533-546. [CrossRef]

74. Costanzo, A. Searchable Database on Performance Results of Underutilised Genetic Resources. Deliv. 2.5. 2019. DIVERSIFOOD Project. Available online: http://www.diversifood.eu/wp-content/uploads/2019/03/ DIVERSIFOOD-D2.5_Searchable-database-available-from-project-website.pdf (accessed on 16 January 2020).

75. Goldringer, I. Varieties and Populations. Innov. Factsheet No. 2. 2017. DIVERSIFOOD. Available online: http://www. diversifood.eu/wp-content/uploads/2018/06/Diversifood_innovation_factsheet2_VarietiesPopulations.pdf (accessed on 16 January 2020).

76. Rivière, P.; Goldringer, I. Response to farmer mass selection in early generation progeny of bread wheat landrace crosses. Renew. Agric. Food Syst. 2015, 30, 190-201. [CrossRef]

77. Leitão, S.T.; Ferreira, E.; Bicho, M.C.; Alves, M.L.; Pintado, D.; Santos, D.; Mendes-Moreira, P.; Araújo, S.S.; Costa, J.M.; Vaz Patto, M.C. Maize Open-Pollinated Populations Physiological Improvement: Validating Tools FOR Drought Tolerance Participatory Selection. Sustainability 2019, 11, 6081.

78. Gallais, A. Théorie de la Sélection en Amélioration des Plantes; Elsevier Masson: Issy-les-Moulineaux, France, 1989.

79. Ceccarelli, S.; Grando, S. Environment of selection and type of germplasm in barley. Breeding for low-yielding conditions. Euphytica 1991, 57, 207-219. [CrossRef]

80. Ceccarelli, S. Efficiency of Plant Breeding. Crop. Sci. 2015, 55, 87-97. [CrossRef]

81. Annicchiarico, P.; Bellah, F.; Chiari, T. Defining Subregions and Estimating Benefits for a Specific-Adaptation Strategy by Breeding Programs: A Case Study. Crop. Sci. 2005, 45, 1741-1749. [CrossRef]

82. Bocci, R.; Andersen, R. Promoting an Enabling Environment for Agrobiodiversity in Europe. Bookl. \#4. 2019. DIVERSIFOOD. Available online: http://www.diversifood.eu/publication/booklet-4-promoting-an-enablingenvironment-for-agrobiodiversity-in-europe/ (accessed on 16 January 2020).

83. Bocci, R.; Chable, V.; Vernooy, R. Biodiversity Management: Dialogue between representatives of Community Seed Banks and international institutions. In Proceedings of the Report from Community Seed Bank Workshop, Rome, Italy, 22 September 2017.

84. Bartha, B. Report on Local Seed Production Systems. Deliv. 4.1. 2017. DIVERSIFOOD. Available online: http://www.diversifood.eu/wp-content/uploads/2017/11/DIVERSIFOOD-D4.1-Report-on-local-seedproduction-system.pdf (accessed on 16 January 2020).

85. Dyer, G.A.; Taylor, J.E. A crop population perspective on maize seed systems in Mexico. Proc. Natl. Acad. Sci. USA 2008, 105, 470-475. [CrossRef] [PubMed]

86. Thomas, M.; Dawson, J.C. Seed exchanges, a key to analyze crop diversity dynamics in farmer-led on-farm conservation. Genet. Resour. Crop. Evol. 2011, 58, 321-338. [CrossRef]

87. Thomas, M.; Thépot, S. Diversifying mechanisms in the on-farm evolution of crop mixtures. Mol. Ecol. 2015, 24, 2937-2954. [CrossRef]

88. Goldringer, I.; Thomas, M. Participatory Approach to Model Community Seed System. Innovation Fact. sheet no. 20. 2019. DIVERSIFOOD. Available online: http://www.diversifood.eu/wp-content/uploads/2018/04/ IF20-Model-community-seed-systems.pdf (accessed on 16 January 2020). 
89. Rossi, A.; Padel, S. Case Study Framework-Report for the completion of Milestone 27: Framework for socio-economic analysis of case studies. In Internal Project Report for Diversifood; Organic Research Centre: Newbury, UK, 2016.

90. Padel, S.; Rossi, A. Case Studies of the Marketing of Products from Newly Bred Lines and Underutilized Crops. Embedding Crop Diversity and Networking for Local High-Quality Food Systems. Deliv. 5.1. 2018. DIVERSIFOOD. Available online: http://www.diversifood.eu/wp-content/uploads/2018/11/DIVERSIFOODD5.1_Case-studies-of-the-marketing-of-products-from-newly-bred-lines-and-underutilized-crops.pdf (accessed on 16 January 2020).

91. Serpolay, E.; Nuijten, E. Toolkit to Foster Multi-Actor Research on Agrobiodiversity. Booklet\#1. 2018. DIVERSIFOOD. Available online: http://www.diversifood.eu/wp-content/uploads/2017/09/toolkit_multi_ actor_research_BAT_web2.pdf (accessed on 16 January 2020).

92. Holzherr, P.; Oehen, B. Communication and Label Concept for Underutilized Crops: Checklist. In Proceedings of the Diversifood Final Congress, Rennes, France, 10-12 December 2018.

93. Meier, C.; Oehen, B. Consumer preferences for vegetables from participatory on-farm breeding networks. In Proceedings of the Diversifood Final Congress, Rennes, France, 10-12 December 2018.

94. Jauhiainen, L.; Keskitalo, M. The potential impact of crop species diversity on food sales in local markets. In Proceedings of the Diversifood Final Congress, Rennes, France, 10-12 December 2018.

95. Kloppenburg, J. Impeding dispossession, enabling repossession: Biological open source and the recovery of seed sovereignty. J. Agrar. Chang. 2010, 10, 367-388. [CrossRef]

96. De Schutter, O. Report of The Special Rapporteur on the Right to Food; United Nations General Assembly: New York, NY, USA, 2014; p. 28.

97. Girard, F.; Frison, C. Introduction: Commoning the seeds: The future of agrobiodiversity and food security. In The Commons, Plant Breeding and Agricultural Research. Challenges for Food Security and Agrobiodiversity; Girard, F., Frison, C., Eds.; Routledge: London, UK, 2018; pp. 1-20.

98. Moore, M.-L.; Riddell, D.J.; Vocisano, D. Scaling Out, Scaling Up, Scaling Deep. Strategies of Non-profits in Advancing Systemic Social Innovation. J. Corp. Citizsh. 2015, 2015, 67-84. [CrossRef]

99. Oehen, B.; Padel, S. Guidance Document and Considerations for the Marketing of Biodiverse Food Products. Bookl. \#7. 2019. DIVERSIFOOD. Available online: http://www.diversifood.eu/wp-content/uploads/2019/09/ booklet7_guidance_doc_WEB_PAGE.pdf (accessed on 16 January 2020).

100. Rey, F.; Chable, V. Innovative Approaches to Embed Diversity in Food Systems: DIVERSFOOD Outcomes from Field to Plate. Bookl. \#6. 2018. DIVERSIFOOD. Available online: http://www.diversifood.eu/wpcontent/uploads/2019/02/booklet6_innovative_approaches_BAT_web_v2.pdf (accessed on 16 January 2020).

101. Ceccarelli, S. Increasing plant breeding efficiency through evolutionary-participatory programs. In More Food: Road to Survival; Pilu, R., Gavazzi, G., Eds.; Bentham ebooks: Sharjah, United Arab Emirates, 2016; pp. 17-40. [CrossRef]

102. De Boef, W.; Subedi, A. Community Biodiversity Management; Earthscan Routledge: London, UK, 2013.

103. Andersen, R.; Shrestha, P. Community Seed Banks: Sharing Experiences from North. and South; Diversifood: Paris, France, 2018.

104. Andersen, R.; Bartha, B.; Goldringer, I. Tools for community biodiversity management. In Proceedings of the Keynote at the Diversifood final congress "Cultivating Diversity and Food Quality", Rennes, France, 10-11 December 2018.

105. Halkier, B. Consumption Challenged: Food in Medialised Everyday Lives; Routledge: London, UK, 2010.

106. Marahaini, M.N.; Jahanshiri, E. Linking data across the value chain of underutilised crops-A multidisciplinary approach. Food Res. 2018, 3, 108-116. [CrossRef]

107. Rey, F.; Bocci, R. 10 SOLIBAM Key Innovations-Cultivating Diversity. 2014. Available online: http://www. solibam.eu/SOLIBAM/booklets_files/SOLIBAM\%20key\%20innovations.pdf (accessed on 16 January 2020).

108. Pedersen, T.; Rey, F. Breeding for Diversity_Political Implications and New Pathways for the Future. 2016. Available online: http://orgprints.org/31147/1/Cobra_net.pdf (accessed on 16 January 2020).

109. Nuijten, E.; Rossi, A.; Serpolay-besson, E. A holistic multi-actor approach to agrobiodiversity enhancement. In Proceedings of the Diversifood Final Congress, Rennes, France, 10-12 December 2018; pp. 87-88.

110. Casañas, F.; Simó, J. Toward an Evolved Concept of Landrace. Front. Plant. Sci. 2017, 8. [CrossRef]

111. Chable, V. A Paradigm Shift. Innov. Factsheet No. 16. 2018. DIVERSIFOOD. Available online: http://www.diversifood. eu/wp-content/uploads/2018/05/Diversifood_IF16_Paradigm_shift-1.pdf (accessed on 16 January 2020). 
112. Kutelmach, M. Exemples of the Different Types of Populations Developed within DIVERSIFOOD. Innovation Factsheet no. 3. 2019. DIVERSIFOOD. Available online: http://www.diversifood.eu/wp-content/uploads/ 2018/06/IF3-Types-of-populations.pdf (accessed on 16 January 2020).

113. Koller, B. Community Seed Banks. Innovation Factsheet no. 1 2016, DIVERSIFOOD. Available online: http: //www.diversifood.eu/wp-content/uploads/2018/06/Diversifood_innovation_factsheet1_CSB-1.pdf (accessed on 16 January 2020).

114. Padel, S.; Rossi, A. Embedding Crop Genetic Diversity in Food Value Chains. Policy Recommendations from the Horizon 2020. Bookl. \#5. 2019. DIVERSIFOOD. Available online: http://www.diversifood.eu/wp-content/ uploads/2017/09/Booklet5Diversifood_WEB.pdf (accessed on 16 January 2020).

115. Winge, T. Seed Legislation in Europe and Crop Genetic Diversity. Sustain. Agric. Rev. 2015, 15, 1-64. [CrossRef]

116. Prip, C.; Fauchald, O.K. Securing Crop Genetic Diversity: Reconciling EU Seed Legislation and Biodiversity Treaties. RECIEL 2016, 25, 363-377. [CrossRef]

(C) 2020 by the authors. Licensee MDPI, Basel, Switzerland. This article is an open access article distributed under the terms and conditions of the Creative Commons Attribution (CC BY) license (http://creativecommons.org/licenses/by/4.0/). 